\title{
Mesozooplankton production, grazing and respiration in the Bay of Bengal: Implications for net heterotrophy
}

\author{
Veronica Fernandes and N. Ramaiah* \\ CSIR-National Institute of Oceanography, Dona Paula Goa 403 004, India \\ *Corresponding author: Tel.: +91-832-2450515; Fax: +91-832-2450602 \\ E-mail: ramaiah@nio.org
}




\section{ABSTRACT}

Mesozooplankton samples were collected from the mixed layer depth along a central (along $88^{\circ} \mathrm{E}$ ) and a western transect in the Bay of Bengal during four seasons covered between 2001and 2006 in order to investigate spatio-temporal variability in their biomass. At these stations, grazing and respiration rates were measured from live zooplankton hauled in from the surface during December 2005. Akin to the mesozooplankton "paradox" in the central and eastern Arabian Sea, biomass in the mixed layer was more or less invariant in the central and western Bay of Bengal, even as the chl $a$ showed marginal temporal variation. By empirical equation, the mesozooplankton production rate calculated to be $70-246 \mathrm{mg} \mathrm{C} \mathrm{m}^{-2} \mathrm{~d}^{-1}$ is on par with the Arabian Sea. Contrary to the conventional belief, mesozooplankton grazing impact was up to $83 \%$ on primary production (PP). Low PP coupled with very high zooplankton production (70\% of PP) along with abundant bacterial production (50\% of the PP; Ramaiah et al. 2009) is likely to render the Bay of Bengal net heterotrophic, especially during the spring intermonsoon. Greater estimates of fecal pellet-carbon egestion by mesozoopankton compared to the average particulate organic carbon flux in sediment traps, implies that much of the matter is recycled by heterotrophic communities in the mixed layer facilitating nutrient regeneration for phytoplankton growth. We also calculated that over a third of the primary production is channelized for basinwide zooplankton respiration that accounts for $\sim 52 \mathrm{M} \mathrm{tC}$ annually. In the current scenario of global warming, if low (primary) productive warm pools like the Bay of Bengal continue to be net heterotrophic, negative implications like enhanced emission of $\mathrm{CO}_{2}$ to the atmosphere, increased particulate flux to the deeper waters and greater utilization of dissolved oxygen resulting in expansion of the existing oxygen minimum zone are imminent.

Key words: Biomass, abundance, copepods, growth rates, spatio-temporal variability

\section{Introduction}


Zooplankton are distributed throughout the world ocean and contribute $21 \mathrm{Gt}$ to its living biomass (Conover 1978). These heterotrophs ingest organic carbon for their growth, production, and respiration and the unassimilated carbon is defecated. Zooplankton grazing is ascribed as the main process responsible for the steady-state of phytoplankton biomass in open-ocean oligotrophic regions (Venrick 1990). This means that phytoplankton is grazed on by zooplankton at the same rate as they are produced. Small bodied zooplankton such as the copepods exerts considerable grazing impact by virtue of their greater abundance (Turner 2004). This may also be the case in the tropics where this group is particularly abundant (McKinnon and Duggan, 2003).

Growth represents one of the most important trophodynamic processes in marine ecosystems (Kiørboe, 1997) is measured in many ways (Runge and Roff, 2000). Temperature, body size, and food availability have been demonstrated to have significant effects on copepod growth (Hirst and Lampitt, 1998). Using temperature and body weight as the important criteria, indirect estimates of zooplankton growth ranging from 0.08 to $0.18 \mathrm{~d}^{-1}$ and production from 24 to $576 \mathrm{mg} \mathrm{C} \mathrm{m}^{-2} \mathrm{~d}^{-1}$ were derived for the Arabian Sea (Roman et al. 2000). We used similar equation to derive the mesozooplankton community growth rate in the Bay of Bengal.

Closely coupled to growth, zooplankton respiration alone is reported to account for 42 $72 \%$ of the total energy (Omori and Ikeda 1984). Del Giorgio and Duarte (2002) reported that respiration consumes more organic matter than estimated autotrophic biomass in the ocean. In tropical oceanic areas where abundances of food organisms for mesozooplankton are generally low vis a vis their neritic counterparts (Paffenhöfer et al. 2003), most of the primary production is mineralized through heterotrophic respiration. In a recent study by Duarte et al (2013) based on the Pacific, Atlantic and the South Indian Ocean estimate, increased respiration due to prevalence of heterotrophic communities is predicted in warmer regions dominated by riverine inputs and low gross primary production and chlorophyll $a$. However, such data is absent from the northern Indian Ocean.

Because of the significant role that zooplankton play in the transformation of organic matter (Marshall 1973), these rates must be quantified in order to understand the energy transfer and matter cycling through zooplankton in pelagic ecosystems. Grazing and metabolic rates have been extensively studied in the coastal and productive areas particularly from the Pacific and Atlantic oceans (Le Borgne 1982, Dam et al. 1995, Zhang et al. 1995, Roman and Gauzens 1997, Harrison et al. 2001, Huskin et al. 2001 a, b, Roman et al. 2002a, b; Calbet et al. 2009; Decima et 
al. 2011; Schukat et al. 2013), In the Indian Ocean, such studies are scarce (Mullin 1966; Smith 1982, Petipa 1985, Sazhina 1985). Since the vast oligotrophic ocean contributes up to $80 \%$ of the global ocean production (Karl et al 1996), studies in these areas need urgent attention. However in the tropics where more than 50 copepod species exist in the surface layer at any given time (Grice and Hart 1962, Timonin 1971), it is impractical to emphasize on rates of individual species.

The Bay of Bengal Process Studies during 2001-2006 was an opportunity for us to carry out our first measurements on growth, production, grazing and respiration rates of copepods in an intensely stratified and low productive tropical ocean environment. For this, we collected mesozooplankton samples from the mixed layer during 4 different seasons during 2001 and 2006 and measured the vital rates during December 2005. Since the spatio-temporal variability in biological parameters in the central and western Bay is only minimal, the grazing and respiration rates measured on ship during winter monsoon period were applied to the mesozooplankton abundance measured during all four cruises undertaken in the Project. By doing this, we derived an annual picture of carbon flow though biological entities in the Bay of Bengal and attempted to answer a key question; whether the zooplankton production in the Bay of Bengal favor net heterotrophy?

\section{Materials and Methods}

\subsection{Sampling and hydrographic characteristics}

Sampling was carried out along $88^{\circ} \mathrm{E}$ in the central-(open ocean transect) and in the western (coastal transect) Bay of Bengal (Fig. 1) during July 6-August 2, 2001 (summer monsoon-SUM), September 14- October 12, 2002 (fall intermonsoon-FIM), April 10- May 10, 2003 (spring intermonsoon-SpIM) and November 25, 2005- January 7, 2006 (winter monsoonWM). Temperature and salinity were recorded with a conductivity- temperature-depth (CTD; Seabird Electronics) rosette at every one degree interval between $9^{\circ} \mathrm{N}$ and $20^{\circ} \mathrm{N}$ in the offshore and coastal transects. These readings were used to discern the mixed layer depths.

\subsection{Chlorophyll a}


Seawater for chlorophyll $a$ (chl $a$ ) measurement was collected by 12-L Go-Flo bottles (General Oceanics, Miami, FL, USA) during CTD casts at 8 depths in the upper $120 \mathrm{~m}$. Duplicate $1 \mathrm{~L}$ samples were filtered through GF/F filters, to extract overnight in $90 \%$ acetone. Under dim lit conditions, chl $a$ fluorescence was measured before and after acidification, by a fluorometer (Turner Designs, USA, 10-AU-005- CE; UNESCO, 1994) following the JGOFS Protocols (UNESCO, 1994).

\subsection{Primary Productivity}

Details of PP measurements carried out during different seasons from the top $120 \mathrm{~m}$ are published in Madhupratap et al (2003). In brief, water samples were collected from 8 depths at predawn in three light and one dark polycarbonate bottles (Nalgene, Germany), inoculated with one ampoule of $\mathrm{NaH}^{14} \mathrm{CO}_{3}$ (Board of Radiation and Isotope Technology, Mumbai; Specific activity $185 \mathrm{kBq}$ ) each and incubated in situ from sunrise to sunset. The contents of the bottles were filtered by GF/F filters ( $47 \mathrm{~mm}$ diameter, $0.7 \mu \mathrm{m}$ pore size, Whatman, USA), fumed with $0.5 \mathrm{~N} \mathrm{HCl}$, and stored in scintillation vials. After adding liquid scintillation cocktail (Sisco Research Laboratory, Mumbai), ${ }^{14} \mathrm{C}$ incorporated in phytoplankton cells was measured in a

scintillation counter (PerkinElmer Wallac 1409 DSA, USA) and expressed as $\mathrm{mg} \mathrm{C} \mathrm{m}^{-2}$ day $^{-1}$ for 0-120 m column (UNESCO, 1994). 


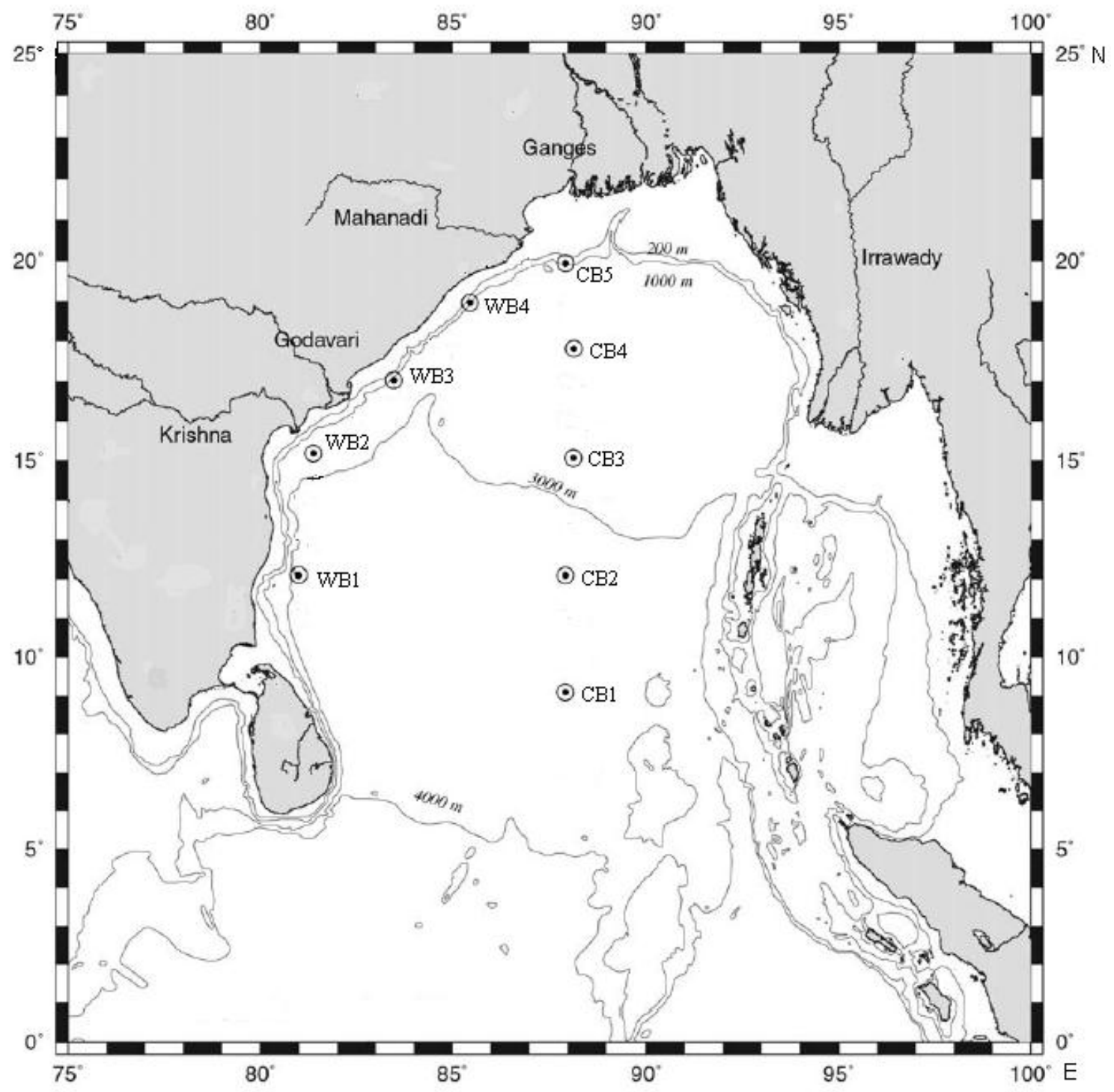

Fig. 1 Study area with sampling locations for mesozooplankton and other physico-chemical parameters. Stations CB1 to CB5 are along the central transect $\left(88^{\circ} \mathrm{E}\right)$ and WB1 to WB4 are in the western Bay of Bengal. 


\subsection{Zooplankton collection, biomass, abundance and copepod species analysis}

Mesozooplankton were collected during the day and the night by vertical tows of a multiple opening/closing plankton net (Multinet ${ }^{\circledR}$ Hydrobios; 200- $\mu$ m mesh size; $0.25-\mathrm{m}^{2}$ mouth area) from $1000 \mathrm{~m}$ depth to surface. The net was hauled up at a speed of $0.8 \mathrm{~m} / \mathrm{s}$, and the volume of water filtered through the net was calculated from the product of depth and mouth area of the net. Only the mixed layer data has been used for this study.

Zooplankton biomass was determined by the displacement volume method (Harris et al. 2000). The biovolume was then converted to carbon equivalent using the relationship detailed by Madhupratap et al. (1981). Using $\leq 50 \%$ sample, zooplankton abundances were estimated using stereozoom microscope (Olympus, Japan, 90x) and identified using standard identification keys (UNESCO 1968; Kasturirangan 1963).

\subsection{Rate measurements}

At each station, surface zooplankton samples were collected using a Bongo net during the WM cruise (November 2005- January 2006) for grazing and respiration measurements and were immediately transferred into $0.45-\mu \mathrm{m}$ pre-filtered surface seawater.

\subsubsection{Growth}

The potential growth rate $(g)$ of mesozooplankton was calculated indirectly by the method of Hirst and Sheader (1997). Average temperature of the upper $120 \mathrm{~m}$ water column was used in the equation considering that zooplankton as well experience the temperatures below the mixed layer during their descent during vertical migration. It was assumed that the predominant copepods comprised all of the measured mesozooplankton biomass after taking out macroscopic gelatinous individuals. Individual copepod weight for the $200-500 \mu \mathrm{m}$ fraction was taken as 2.04

$\mu \mathrm{g} \mathrm{C}$ (Roman et al. 2000) and rates of copepod production were derived from the product of the estimated growth rate and biomass.

Intrinsic growth rate $\mathbf{g}\left(\mathrm{d}^{-1}\right)=0.0732 \times 10^{0.0246 T} / \mathrm{W}_{c}{ }^{0.2962}$ where, $T ;{ }^{\circ} \mathrm{C}$ is the average temperature of the top $120 \mathrm{~m}$ water column and $\mathrm{W}_{\mathrm{c}}, \mu \mathrm{g} \mathrm{C}$ individual $^{-1}$ is the copepod carbon weight Production $\mathbf{P}\left(\mathrm{mg} \mathrm{C} \mathrm{m}^{-2} \mathrm{~d}^{-1}\right)=\mathrm{B} \times \mathrm{g}, \quad$ where, $\mathrm{B}, \mathrm{mg} \mathrm{C} \mathrm{m}^{-2}$ is the zooplankton biomass.

\subsubsection{Grazing}


Zooplankton grazing was measured employing the gut fluorescence technique (Mackas and Bohrer 1976) with some modifications. For measuring the gut pigments, at zero time itself, $\sim 25$ $\mathrm{ml}$ seawater was filtered by $200 \mu \mathrm{m}$ mesh. Under low power and dim light, 30 copepods were picked and transferred into $10 \mathrm{ml} 90 \%$ cold acetone maintained at $4^{\circ} \mathrm{C}$ in the dark without homogenization (Morales et al. 1991) for extraction for $24 \mathrm{~h}$. Similar number of copepods were picked every $15 \mathrm{~min}$ for $150 \mathrm{~min}$ and the same procedure was repeated. After extraction, the sample was thawed and chlorophyll (chl) $a$ was measured in a fluorometer (AU-10 Turner designs, USA). The extract was then acidified with $0.1 \mathrm{ml}$ of $10 \% \mathrm{HCl}$ and fluorescence measured again for phaeopigments. The calculations for the gut pigments mentioned below were done according to (Harris et al. 2000).

Chl $\boldsymbol{a}\left(\mathrm{ng}\right.$ copepod $\left.^{-1}\right)=(\mathrm{T} /(\mathrm{T}-1)) \times(\mathrm{Rb}-\mathrm{Ra}) \times \mathrm{Fd} \times \mathrm{v} / \mathrm{n}$

Phaeopigment $\left(\right.$ ng copepod $\left.{ }^{-1}\right)=(\mathrm{T} /(\mathrm{T}-1)) \times((\mathrm{T} \times \mathrm{Ra})-\mathrm{Rb}) \times \mathrm{Fd} \times \mathrm{v} / \mathrm{n}$

where; $\mathrm{T}=$ acidification coefficient $(\mathrm{Rb} / \mathrm{Ra}$ obtained through the calibration of the fluorometer); $\mathrm{Rb}=$ reading before acidification; $\mathrm{Ra}=$ reading after acidification

$\mathrm{Fd}=$ flourometer calibration factor $\left(\mathrm{ng} \operatorname{liter}^{-1}\right) ; \mathrm{v}=$ volume of extraction (ml);

$\mathrm{n}=$ number of copepods

Gut content $\left(\mathrm{G}, \mathrm{ng}\right.$ pigment copepod $\left.{ }^{-1}\right)=(1.51 \mathrm{x}$ conc. of phaeopigment $)+$ conc. of chl $a$.

The gut evacuation rate constant $(\mathrm{K})$ was calculated from the decline in gut pigment content with time $\mathrm{t}: \mathbf{G}_{\mathbf{t}}=\mathrm{G}_{0} \mathrm{x} \mathrm{e}^{-\mathrm{Kt}} \quad$ where; $\mathrm{G}_{\mathrm{t}}=$ pigment concentration at time $\mathrm{t} ; \mathrm{G}_{0}=$ pigment concentration immediately after collection (time $\mathrm{t}_{0}$ ).

Ingestion rates (I, ng chl eq. copepod $^{-1} \mathrm{~h}^{-1}$ ) were calculated from the product of gut pigment content and gut evacuation rate constant: $\mathbf{I}=\mathrm{G} \times \mathrm{K}$.

Egestion (fecal pellet production; E) was assumed to be $30 \%$ of I (Conover 1978). Daily grazing rate of the mesozooplankton community $\left(\mathrm{mg} \mathrm{C} \mathrm{m}^{-2} \mathrm{~d}^{-1}\right)$ was estimated as the product of ingestion rate, copepod abundance and $24 \mathrm{hrs}$ of a day. Here we assumed that copepods of similar body sizes have similar ingestion rates under the same environmental conditions (Morales et al. 1990). The carbon: chl $a$ ratio was taken as 50 (Banse 1988).

\subsubsection{Respiration}

Respiration rate was measured following Mayzaud and Dallot (1973). For this, 30 copepods and streptomycin $\left(50 \mathrm{mg} \mathrm{L}^{-1}\right)$ were added to a set of two $125 \mathrm{ml}$ bottles containing 0.2 
$\mu \mathrm{m}$ filtered seawater. Replicates of experimental, and control bottles without copepods were incubated at room temperature $\left(28^{\circ} \mathrm{C}\right)$ in dark for $12 \mathrm{~h}$. Care was taken to avoid any air bubble while filling the bottles or at the time of transferring the copepods. At the end of the incubation, it was ensured that the animals were swimming and alive. The bottles were fixed with Winkler A and $\mathrm{B}$ and the initial and the final concentrations of dissolved oxygen were estimated by the standard Winkler method (Grasshoff et al. 1983) using 665 Dosimat Metrohm, Switzerland. Oxygen respired by copepods was calculated according to Omori and Ikeda (1984):

$\mathbf{R}\left(\mu 1 \mathrm{O}_{2}\right.$ copepod $\left.^{-1} \mathrm{~d}^{-1}\right)=\left(\left(\mathrm{C}_{0}-\mathrm{C}_{\mathrm{t}}\right)-\left(\mathrm{C}_{0}-\mathrm{C}_{\mathrm{t}}{ }^{\prime}\right)\right) \times\left(\mathrm{V}_{\mathrm{e}}-\mathrm{V}_{\mathrm{z}}\right) /(\mathrm{t} \times \mathrm{N})$

Where $\mathrm{C}_{0}=$ Oxygen concentration $\left(\mathrm{ml} \mathrm{L}^{-1}\right)$ at time $0, \mathrm{C}_{\mathrm{t}}=$ oxygen concentration $\left(\mathrm{ml} \mathrm{L}^{-1}\right)$ in experimental bottle, $\mathrm{C}_{\mathrm{t}}{ }^{\prime}=$ oxygen concentration $\left(\mathrm{ml} \mathrm{L}^{-1}\right)$ in control, $\mathrm{V}_{\mathrm{e}}=$ volume of experimental bottle in litres, $\mathrm{V}_{\mathrm{z}}=$ volume of zooplankton, $\mathrm{t}=$ incubation time in days, $\mathrm{N}$ = number of copepods.

Since zooplankton are ammonotelic animals, a respiration quotient of 0.97 was used for converting oxygen consumed into carbon mineralized (Omori and Ikeda 1984). The values of respiration rate per copepod obtained during this cruise were multiplied with the number of copepods per square meter area sampled from the mixed layer during each of the four cruises to get the daily respiration rates for zooplankton community as done for ingestion rates.

\subsection{Basin-wide energy conversion estimates}

For obtaining the basin-wide estimates of carbon, data on zooplankton production (ZP), grazing, egestion, respiration and primary production (PP) in carbon units per meter square per day for four seasons using the above methods were extrapolated for 365 days of the year and basin-wide area of $2.2 \times 10^{6} \mathrm{~km}^{2}$ of the Bay of Bengal to yield values in $\mathrm{M} \mathrm{tC} \mathrm{y}^{-1}$.

\subsection{Data analysis}

Differences in biomass and numerical abundance of zooplankton and all the physicochemical parameters in the study were tested separately for spatial and temporal differences with Friedman Anova using software Statistica 6.0. Correlation analysis was carried out to see the effect of environmental variables on the zooplankton vital rates with Microsoft Excel Data analysis software.

\section{Results}




\subsection{Environmental data}

Surface salinity varied from 27.7 to 33.9 in the central Bay and from 20.7 to 34.0 in the western Bay. Salinity was lower during SUM and FIM and was the highest during SpIM. Except during WM, the sea surface temperature (SST) was usually $>28^{\circ} \mathrm{C}$ with the maxima generally during SpIM followed by FIM along both transects. The mixed layer varied between $2 \mathrm{~m}$ and 55 $\mathrm{m}$ during the four sampling periods, mostly shoaling northwards during SUM and FIM periods. Details on the hydrography are given in Prasanna Kumar et al. (2007, 2010b).

Among seasons, the column-integrated chlorophyll (chl) $a$ varied significantly from 9 to $23 \mathrm{mg} \mathrm{m}^{-2}$ in the central Bay (Chi sqr. $[N=5, d f=3]=9.7, \boldsymbol{p}<\mathbf{0 . 0 5}$ ) with the highest concentration during winter monsoon. In the western Bay, chl $a$ varied from 11 to $43 \mathrm{mg} \mathrm{m}^{-2}$ with the highest value during SpIM, and moderate during WM. However the variation was not significant (Chi sqr. $[N=4, d f=3]=3.9 p>0.05)$. The chl-carbon biomass ranged from 518 to $1023 \mathrm{mg} \mathrm{C} \mathrm{m}^{-2}$ in the central- and from 688 to $1212 \mathrm{mg} \mathrm{C} \mathrm{m}^{-2}$ in the western Bay (Ramaiah et al. 2010). The lowest Chl $a$ biomass was observed during SUM in both transects. Subsurface Chl $a$ maximum was found between 40 and $60 \mathrm{~m}$ in the central Bay and between 20 and $60 \mathrm{~m}$ in the western Bay and was. deepest, at $80 \mathrm{~m}$ during the SpIM season in both transects.

Detailed values of primary productivity are available in Ramaiah et al. (2010). In brief, average column integrated primary production in the central Bay varied significantly from 144 mg C m${ }^{-2} \mathrm{~d}^{-1}$ during the SUM to $375 \mathrm{mg} \mathrm{C} \mathrm{m}^{-2} \mathrm{~d}^{-1}$ during WM (Chi Sqr. $[\mathrm{N}=5, \mathrm{df}=3]=8.28 \boldsymbol{p}<$ 0.05). In the western Bay, PP varied marginally from $280 \mathrm{mg} \mathrm{C} \mathrm{m}^{-2} \mathrm{~d}^{-1} \mathrm{during}$ the $\mathrm{WM}$ to $366 \mathrm{mg}$ $\mathrm{C} \mathrm{m}^{-2} \mathrm{~d}^{-1}$ during SPIM (Chi Sqr. $[\mathrm{N}=4, \mathrm{df}=3]=3.60 p>0.05$ ).

\subsection{Zooplankton biomass, abundance and composition in the mixed layer}

Since zooplankton biomass (CB: Chi Sqr. $[\mathrm{N}=4$, df = 4] = 3.0 p>0 .05 and WB: Chi Sqr. $[\mathrm{N}=4, \mathrm{df}=3]=2.1 p>0.05)$ and abundance $(\mathrm{CB}$ : Chi Sqr. $[\mathrm{N}=4, \mathrm{df}=4]=0.60 p>0.05$; WB: Chi Sqr. $[\mathrm{N}=4, \mathrm{df}=3]=0.30 p>0.05$ ) showed insignificant variability among stations in both transects sampled, the data presented hereafter will be average and standard deviation values of 5 stations in the central Bay and 4 stations in the western Bay for four sampling periods.

Zooplankton biomass integrated for the mixed layer varied insignificantly during the sampled periods. In the central Bay, it ranged from $360 \mathrm{mg} \mathrm{C} \mathrm{m}^{-2}$ during WM (Table 1) to 812 
mg C m${ }^{-2}$ during SpIM (Chi Sqr. $[\mathrm{N}=5, \mathrm{df}=3]=1.16 p>0.05$ ). In the western Bay, the biomass was low during SUM and FIM (295 and $291 \mathrm{mg} \mathrm{C} \mathrm{m}^{-2}$ ) and was the highest during SpIM (1012 $\mathrm{mg} \mathrm{C} \mathrm{m}^{-2}$, Chi Sqr. $\left.[\mathrm{N}=4, \mathrm{df}=3]=1.50 \mathrm{p}>0.05\right)$.

Abundance of zooplankton individuals in the central Bay varied from 6785 to 22881 ind. $\mathrm{m}^{-2}$ and from 10256 and 34763 ind. $\mathrm{m}^{-2}$ in the western Bay (Table 1). In both transects, seasonal average was the highest for the intermonsoons and the lowest for SUM (Chi Sqr. [N = 5, df = 3] $=1.0 p>0.05$; WB: Chi Sqr. $[\mathrm{N}=4, \mathrm{df}=3]=6.0 p>0.05)$. Also, the average zooplankton in the western Bay (27500 ind. $\mathrm{m}^{-2}$ ) was nearly double that in the central (15398 ind. $\mathrm{m}^{-2}$ ) Bay.

Table 1. Mean biomass ( $\mathrm{mg} \mathrm{C} \mathrm{m}^{-2}$ ) and abundance (ind. $\mathrm{m}^{-2}$ ) of mesozooplankton, percentage (in parenthesis) of copepods* and their dominant species occurring in the mixed layer during different seasons.

\begin{tabular}{|c|c|c|c|c|}
\hline & $\begin{array}{l}\text { Summer monsoon } \\
2001\end{array}$ & $\begin{array}{l}\text { Fall intermonsoon } \\
2002\end{array}$ & Winter monsoon 2005 & $\begin{array}{l}\text { Spring Intermonsoon } \\
2003\end{array}$ \\
\hline \multicolumn{5}{|l|}{ Central Bay } \\
\hline Biomass & $552 \pm 381$ & $544 \pm 390$ & $360 \pm 247$ & $812 \pm 892$ \\
\hline Abundance & $6785(87) * \pm 7191$ & $21973(74) * \pm 26448$ & $9953(74) * \pm 9954$ & $22881(78) * \pm 26805$ \\
\hline $\begin{array}{l}\text { Dominant } \\
\text { species }\end{array}$ & $\begin{array}{l}\text { Oncaea venusta } \\
(37)\end{array}$ & $\begin{array}{l}\text { Paracalanus indicus } \\
(26) \\
\text { O. venusta }(23)\end{array}$ & $\begin{array}{l}\text { O. venusta }(20) \text {, } \\
\text { C. } \operatorname{arcuicornis~}(10) \text {, } \\
\text { Oithona similis }(9)\end{array}$ & $\begin{array}{l}\text { C. arcuicornis (22), } \\
\text { O.venusta (13) }\end{array}$ \\
\hline \multicolumn{5}{|l|}{ Western Bay } \\
\hline Biomass & $295 \pm 305$ & $291 \pm 201$ & $494 \pm 217$ & $1012 \pm 1226$ \\
\hline Abundance & $10256(88) * \pm 17014$ & $34763(81) * \pm 14782$ & $30565(82) * \pm 21766$ & $34417(82) * \pm 49626$ \\
\hline species & $\begin{array}{l}\text { P. indicus }(17) \text {, } \\
\text { O. venusta }(15)\end{array}$ & $\begin{array}{l}\text { O. venusta }(13), \\
\text { Acartia spinicauda }(9)\end{array}$ & $\begin{array}{l}\text { O. venusta }(19) \text {, } \\
\text { P. indicus }(8)\end{array}$ & $\begin{array}{l}\text { O.venusta }(7), \\
\text { C. } \operatorname{arcuicornis}(7), \\
\text { Pleuromamma indica }(7)\end{array}$ \\
\hline
\end{tabular}

Zooplankton was represented by the predominant group Copepoda varying between 74 and $87 \%$ in the central- and $81-88 \%$ of the total numerical abundance in the western Bay (Table 1). The copepods were mostly small sized and Oncaea venusta was generally the most abundant species during all sampling periods. This species contributed 13-37\% to the total copepod abundance in the central Bay with the maximum abundance during SUM and, in the western Bay, it ranged from $7 \%$ to $19 \%$. In all other seasons when its abundance was relatively less, 
species such as Paracalanus indicus, Clausocalanus arcuicornis and Acartia spinicauda codominated.

\subsection{Zooplankton growth and production rates}

Growth rate, derived mostly as a function of temperature in the top $120 \mathrm{~m}$, did not vary between stations in $\mathrm{CB}$ (Chi Sqr. $[\mathrm{N}=4, \mathrm{df}=4]=3.6 p>0.05)$ and $\mathrm{WB}($ Chi Sqr. $[\mathrm{N}=4, \mathrm{df}=$ $3]=2.7 \mathrm{p}>0.05)$. The variation between seasons was significant only in the CB (Chi Sqr. $[\mathrm{N}=5$, df $=3]=9.7 p<0.05)$ where it averaged $0.24 \mathrm{~d}^{-1}$ during SUM and FIM, and $0.26 \mathrm{~d}^{-1}$ during WM and SpIM (Fig. 2a). In the western transect, it was the lowest at $0.23 \mathrm{~d}^{-1}$ during WM, moderate at $0.25 \mathrm{~d}^{-1}$ during FIM and higher at $0.26 \mathrm{~d}^{-1}$ during SUM (Chi Sqr. $[\mathrm{N}=3, \mathrm{df}=3]=0.2 p>0.05$ ).

Using the growth rate and measured biomass in different seasons, we calculated the secondary/zooplankton production rate (Fig.2b). It ranged from 94 to $225 \mathrm{mg} \mathrm{C} \mathrm{m}^{-2} \mathrm{~d}^{-1}$ in the central Bay (Chi Sqr. $[\mathrm{N}=5, \mathrm{df}=3]=1.3 p>0.05$ ) and from 70 to $247 \mathrm{mg} \mathrm{C} \mathrm{m}^{-2} \mathrm{~d}^{-1}$ in the western Bay, Chi Sqr. $[\mathrm{N}=3, \mathrm{df}=3]=1.0 p>0.05)$. Zooplankton production greater during SpIM in both transects. 

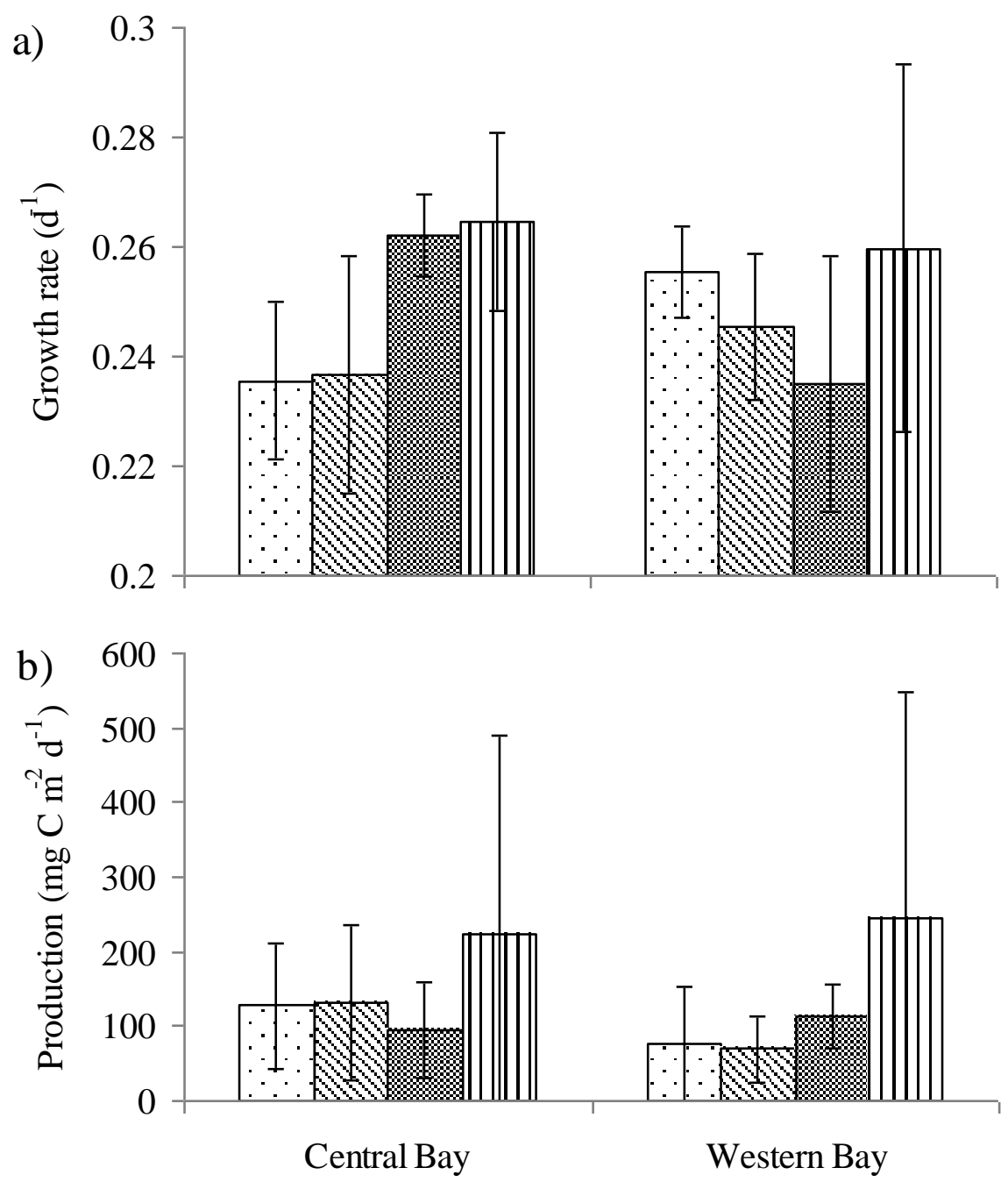

Fig. 2 Temporal variation of copepod growth and production rates in the central and western Bay of Bengal. Error bars indicate standard deviation of 5 stations in the central Bay and 4 stations in the western Bay during summer monsoon (SUM), fall intermonsoon (FIM), winter monsoon (WM) and spring intermonsoon (SpIM) season. 


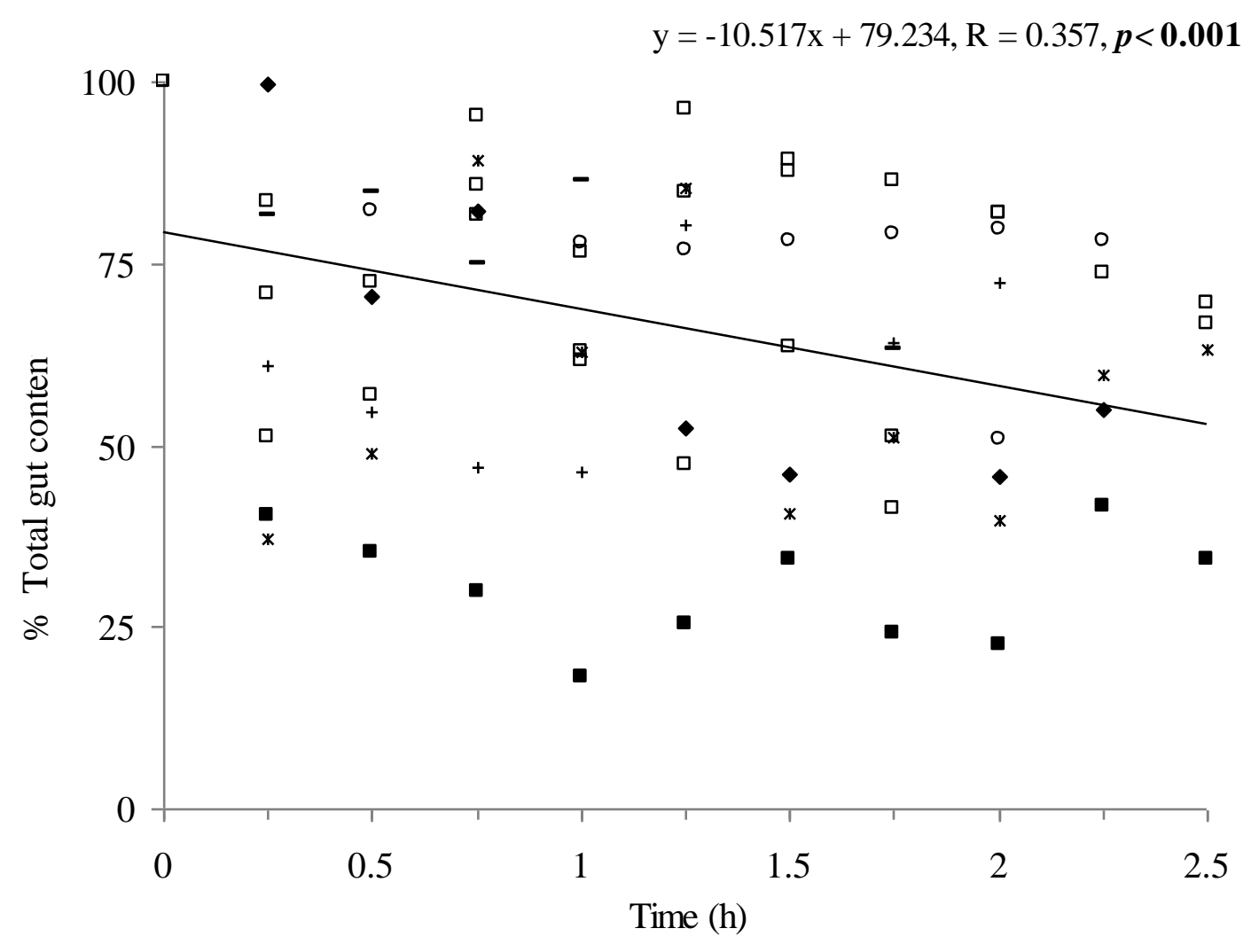

Figure 3. Variation in copepod gut pigment content (chl $a$ and phaeopigments) with increasing starvation time 


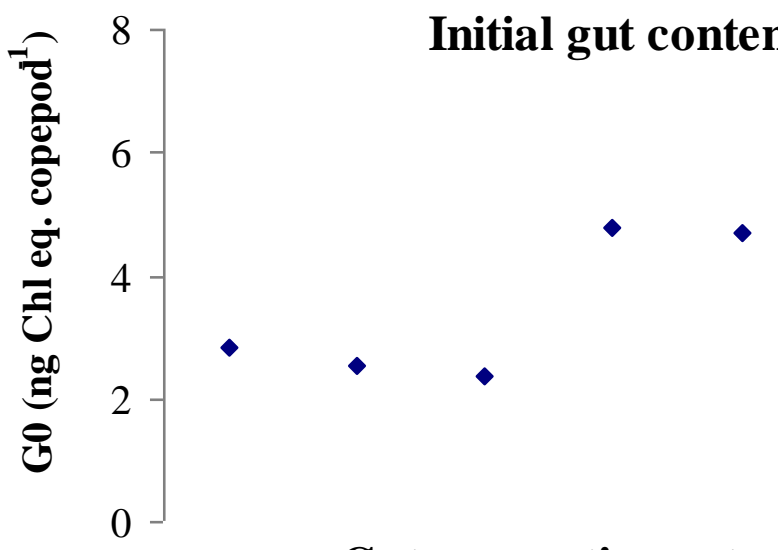

Gut evacuation rate constant
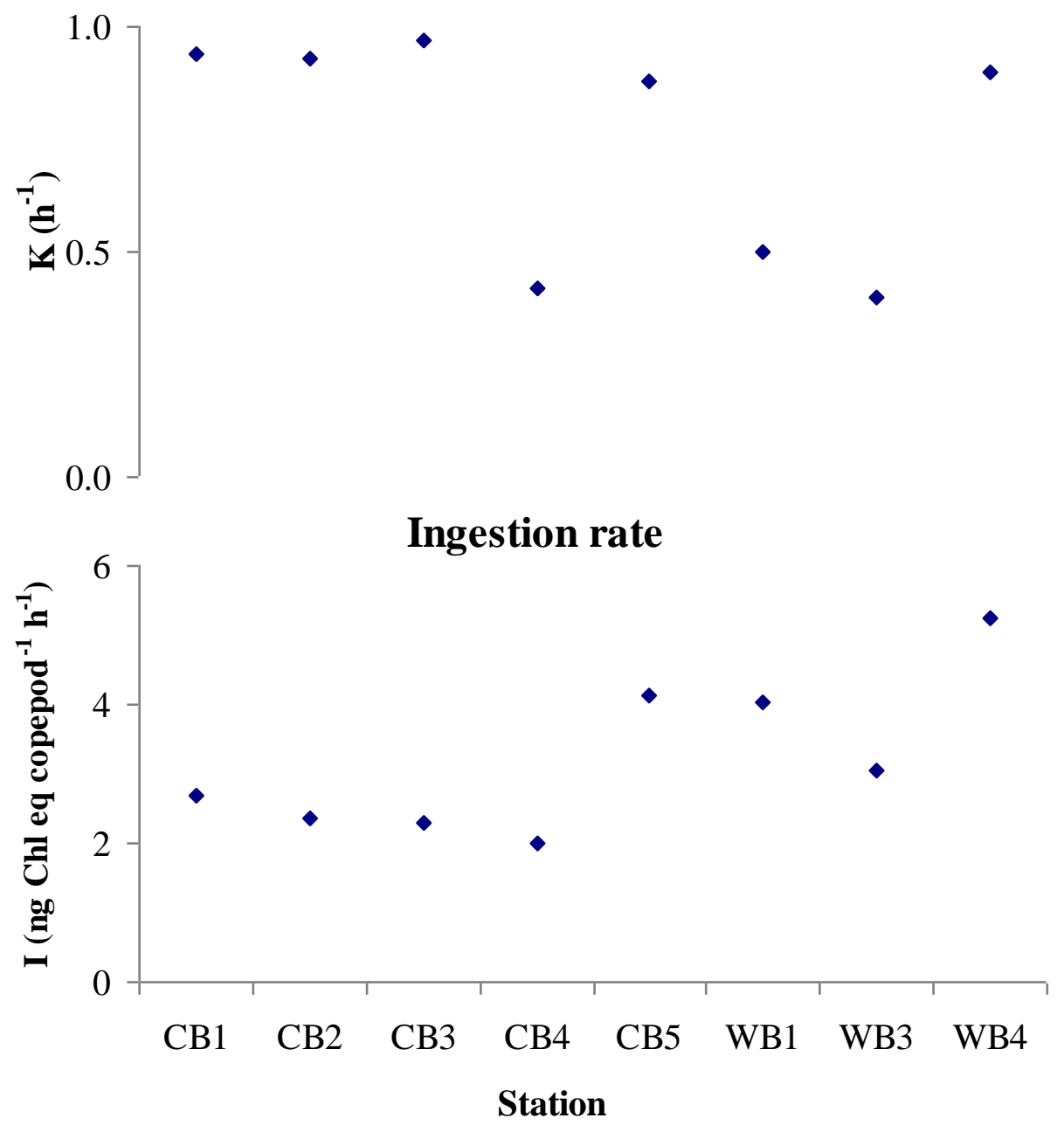

Fig.4 Spatial variability of initial gut content $\left(\mathrm{G}_{0}\right)$, gut evacuation rate constant $(\mathrm{K})$ and ingestion rate (I) measured in copepods at different stations in the Bay of Bengal. 


\subsection{Gut pigments, ingestion and egestion rates of copepods}

During the course of gut evacuation experiment, the gut content significantly decreased with increasing starvation time (Fig 3). Initial chl $a$ concentrations from guts of freshly caught copepods during the measurements of gut fluorescence at various stations were found to be ranging from 1.8 to $5.2 \mathrm{ng}$ copepod $^{-1}$. Similarly, the phaeopigment concentration ranged from 0.1 to $1.7 \mathrm{ng}$ copepod $^{-1}$. The total initial pigment concentration $\left(\mathrm{G}_{0}\right)$ comprising the chlorophyll $a$ and the phaeopigment in guts of live copepods ranged from 2.4 to $8 \mathrm{ng}$ chl eq copepod ${ }^{-1}$ (Fig. 4). In the central Bay, $\mathrm{G}_{0}$ was higher at station CB4 and CB5 and in the western Bay; it was higher at all the stations. The chlorophyll contained in the guts of the copepods in the western Bay was double than in the central Bay.

The gut evacuation rate $(\mathrm{K})$ constant measured at different stations during WM cruise ranged from 0.4 to $0.94 \mathrm{~h}^{-1}$, giving a gut clearance time estimate of 1.1-2.5 h (Fig. 4). The ingestion rate observed was 2.0-5.25 $\mathrm{ng}$ chl eq. copepod ${ }^{-1} \mathrm{~h}^{-1}$ and the rate of egestion of fecal pellets was assumed to be 0.6 and $1.58 \mathrm{ng}$ chl eq. copepod ${ }^{-1} \mathrm{~h}^{-1}$. Complementing the abundance of zooplankton in various seasons, the daily grazing rate of the community ranged from 26-88 $\mathrm{mg} \mathrm{C} \mathrm{m} \mathrm{d}^{-2}$ in the central Bay and 39-133 $\mathrm{mg} \mathrm{C} \mathrm{m}^{-2} \mathrm{~d}^{-1}$ in the western Bay (Fig. 5a). Similarly, the fecal pellet egestion was estimated to be $8-26 \mathrm{mg} \mathrm{C} \mathrm{m}^{-2} \mathrm{~d}^{-1}$ in the central Bay and $12-40 \mathrm{mg}$ $\mathrm{C} \mathrm{m}^{-2} \mathrm{~d}^{-1}$ in the western Bay (Fig. 5b). Correspondingly, the amount of phytoplankton-carbon ingested by grazers, and the amount lost to the surrounding water as fecal pellets was higher during both the intermonsoons in the central Bay and also during WM in the western Bay. Similarly, these rates in the western Bay were also twice that in the central Bay. 

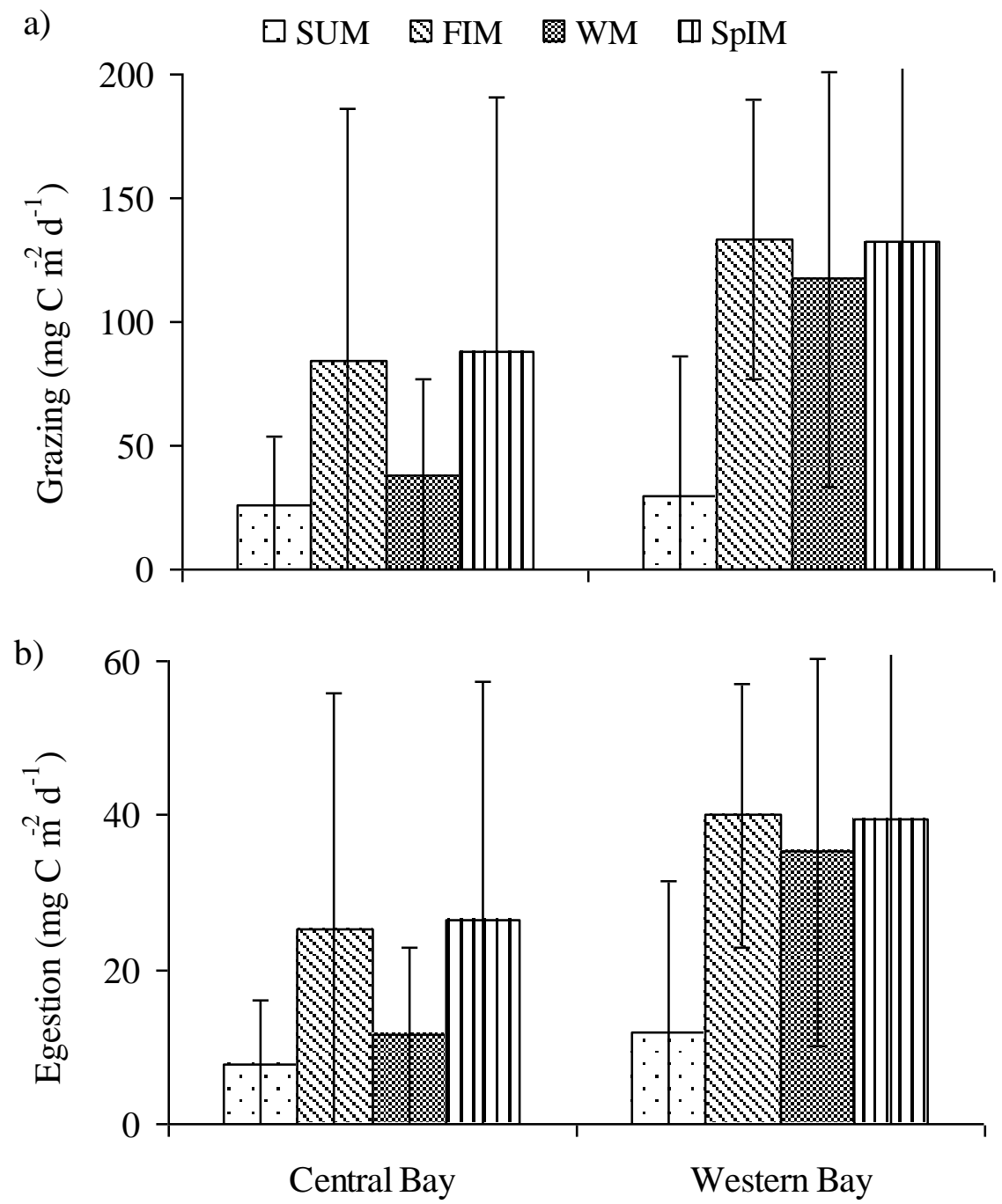

Fig. 5. Temporal variation in rates of copepod grazing and egestion of fecal pellets in the central and western Bay of Bengal. Error bars indicate standard deviation in each season of 5 stations in the central Bay and 4 stations in the western Bay. 

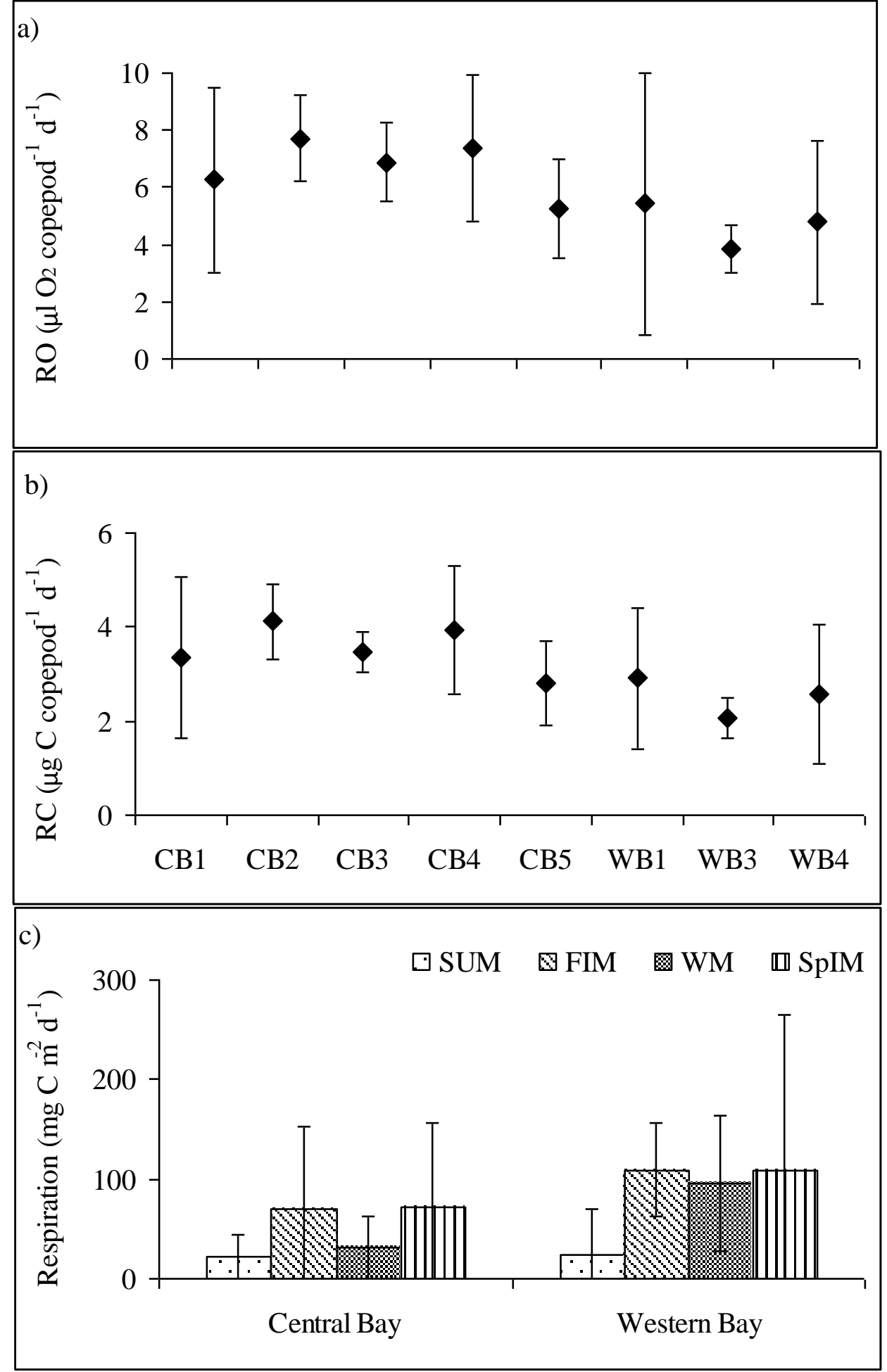

Fig. 6 Spatial variation in copepod respiration in terms of oxygen consumed (RO), carbon requirement $(\mathrm{RC})$ and, temporal variation of respiration by zooplankton community in the mixed layer of central and western Bay of Bengal. Error bars in figures a) and b) indicate standard 
deviation of three measurements taken at each station. Error bars in figure c) indicate standard deviation in each season of 5 values (stations) in the central Bay and 4 stations in the western Bay.

\subsection{Respiration rates of copepods}

The oxygen consumption rates for respiration (RO; Fig. 6a) by copepods collected from the surface waters of the Bay of Bengal varied from 3.9 to $7.7 \mu 1 \mathrm{O}_{2} \operatorname{copepod}^{-1} \mathrm{~d}^{-1}$ at different stations during the WM period. The corresponding carbon requirement (RC; Fig. 6b) was 2.24.1 $\mu \mathrm{g} \mathrm{C}$ copepod ${ }^{-1} \mathrm{~d}^{-1}$. Higher values of respiration occurred in the central Bay and the lower values occurred in the western Bay. The carbon mineralized due to mesozooplankton community respiration in the mixed layer ranged from 21-71 $\mathrm{mg} \mathrm{C} \mathrm{m}^{-2} \mathrm{~d}^{-1}$ in the central Bay (Fig. 6c), with higher values during intermonsoons. This variation in zooplankton community respiration is mainly due to the variation in zooplankton biomass during the various sampling periods. In the western Bay, the rate in the range of $24-109 \mathrm{mg} \mathrm{C} \mathrm{m}^{-2} \mathrm{~d}^{-1}$ was similarly higher during all but SUM season.

\subsection{Ratios of zooplankton grazing, respiration and production to primary production}

The zooplankton grazing ratio (G: PP) ranged from 25\% during WM to $83 \%$ during SpIM in the CB (Fig. 7a). In the WB, it ranged from $18 \%$ during SUM to $71 \%$ during WM. Varying similarly, the daily respiration rates (Fig. $7 b$ ) were $21 \%-68 \%$ of the daily PP in the CB with higher value in SpIM. In the WB, it ranged from $14 \%$ to $58 \%$ with higher values in WM and SpIM. Ratio of zooplankton production to primary production (ZP: PP) was a minimum of $50 \%$ during FIM and WM and 128\% during SpIM in the CB (Fig.7c). In the WB, it was 26\% in FIM to $118 \%$ in SpIM. The variability was very large during SpIM, where aberrantly large biomass was found at only 2 stations. 


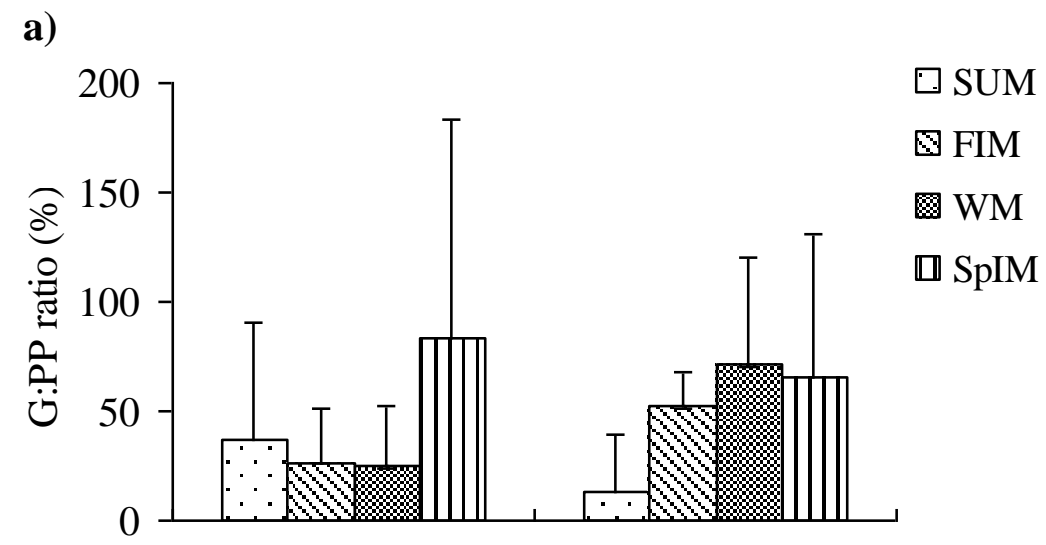

b)

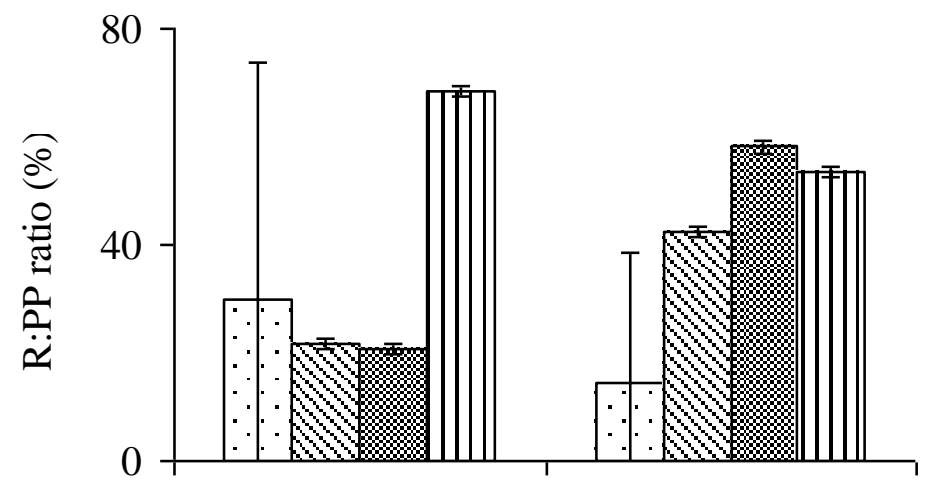

c)

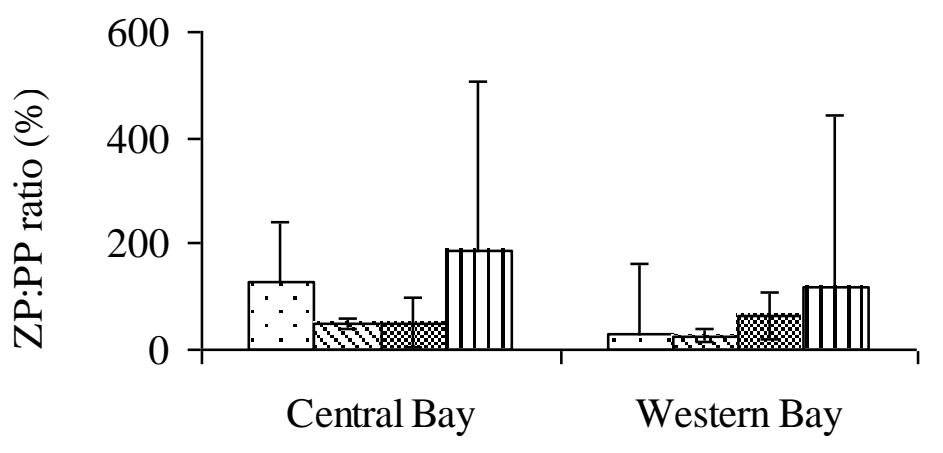

Fig. 7. Seasonal variation of ratios of zooplankton- production $(\mathrm{ZP})$, grazing $(\mathrm{G})$ and respiration (R) to primary production (PP) in the Bay of Bengal. Error bars indicate standard deviation in each season of 9 values ( 5 stations in the central Bay and 4 stations in the western Bay). 


\section{Discussion}

\subsection{Temporal variability in Zooplankton biomass}

Spatial and/or temporal variability is largely governed by the seasonal changes in physico-chemical parameters, that affect concentrations of nutrients and chl $a$. Upwelling in the central Arabian Sea, and along the west coast of India during summer monsoon (June-August), leads to very high primary production supporting the extant zooplankton biomass (445-616 mg C $\mathrm{m}^{-2}$ ). From the earlier studies, eg., Joint Global Ocean Flux Study, it is observed that the mesozooplankton biomass in the mixed layer is more or less invariant (Madhupratap et al. 1996). Winter cooling during December-February and microbial loop during fall- (September-October) and spring- (March-May) intermonsoons help sustain such invariant biomass (Madhupratap et al. 1996).

Unlike in the western Indian Ocean as well as along the west coast of India, the Bay of Bengal -the eastern arm of the Indian Ocean- does not show signs of strong upwelling during any season (Vinayachandran and Shetye 1991). Observations during the International Indian Ocean Expedition (Panikkar and Rao 1973) and those later (see Madhupratap et al. 2003) highlight winter monsoon peaks in zooplankton biomass. Recently, spatial variability in zooplankton biomass, abundance and composition in the Bay during summer monsoon and fall intermonsoon seasons were reportedly attributed to mesoscale cold core eddies (Fernandes 2008; Fernandes and Ramaiah 2009; Fernandes and Ramaiah 2013).

After taking all the 4 study periods into account, we observed a general lack of significant spatial and temporal variability in mesozooplankton biomass and abundance in the Bay of Bengal. Incidently, highest zooplankton biomass was found in the western bay during the spring intermonsoon, where the highest chlorophyll $a$ concentrations were also noticed (Ramaiah et al 2010). The analysis of $\delta{ }^{15} \mathrm{~N}$ values by Kumar and Ramesh (2005) has clearly shown that the phytoplankton in the central region was supported by new production through nutrients injected from the deep water and one such likely mechanism is cold core eddies as reported variously by Prasanna Kumar et al (2004, 2007, 2010). However in the western regions, terrestrial source was major. Some authors (Madhupratap et al. 1996; Jyothibabu et al. 2008) have frequently attributed the enhanced zooplankton stocks during SpIM to the microbial loop which dominates during this season in seas around India, when water column is thermally stratified. The same phenomenon was observed recently off the Gulf of Mannar and Palk Bay in the southern Bay of Bengal 
(Anjusha et al. 2013). There are not many studies reporting the seasonal variability in zooplankton biomass from the tropical open oceans. Most recent study by Yamaguchi et al (2015) investigating epipelagic zooplankton in the top $150 \mathrm{~m}$ along $150^{\circ} \mathrm{E}$ has also shown that the biomass and its seasonality is lowest in the lower latitudes.

\subsection{Grazing}

Mesozooplankton grazing rate estimations in the tropical water are limited. In the Indian Ocean, the only grazing study was carried out in the Arabian Sea based on the dual isotope uptake method (Roman et al 2000). Scant biological measurements in the past half century reveal low primary production (reviewed in Prasanna Kumar et al 2010b) and zooplankton biomass (Achuthankutty et al 1980, Nair et al 1981, Rakhesh et al 2006) in the Bay of Bengal. However no mesozooplankton grazing measurements have ever been documented. From studies of Roman and Gauzens (1997), regions like this where diatoms and copepods predominate, hold a high grazing potential. The gut fluorescence method of estimating the ingestion rates of copepods is in use for more than 3 decades and comparisons with direct measurements of ingestion rates by other methods have yielded similar values (Peterson et al. 1990) To be contextual, we have compared the available data on grazing rates and ratios from the subtropical and temperate regions with the present observations (Table 2).

In this study, the gut fluorescence ranging from 1.8-5.2 $\mathrm{ng}$ chl $a$ copepod $^{-1}$ in freshly caught copepods is comparable to the range of $0.1-16 \mathrm{ng} \operatorname{chl} a$ ind $^{-1}$ found in the temperate waters. Though higher gut fluorescence coinciding with higher chl $a$ levels was found in the western Bay, the lack of significant positive correlation between them during WM is suggestive that gut pigment does not always relate to chlorophyll availability in the environment. As Besiktepe et al. (2005) and many others point out, such poor relationships are attributed to many factors such as evacuation of guts by copepods before freezing and even changes in phytoplankton composition at sampling stations. As the degree of pigment destruction during the digestion processes is highly variable in this method (Dam and Peterson, 1988; Head and Harris, 1996), no correction for pigment destruction was made on the assumption that there was little pigment destruction at the low food concentration (Penry and Frost, 1991). The number of phytoplankton cells found in the euphotic zone including all the study periods ranged from $40-$ 23296 cells L$^{-1}$ (See Paul et al. 2008). 
The values of gut evacuation rate constants $\left(\mathrm{K}: 0.4-0.94 \mathrm{~h}^{-1}\right)$ and gut transit times (1.1 to $2.5 \mathrm{~h}$ ) are similar to those reported in the literature on subtropical copepods (Table 2). Dam and Peterson (1988) found a gut evacuation rate constant of $3.5 \mathrm{~h}^{-1}$ for copepods at a temperature of $20^{\circ} \mathrm{C}$ and have shown that the rate constant is higher at higher temperature. Relatively slower gut evacuation rates were observed by some in the temperate oceans (Dagg and Wyman 1983; Tsuda and Nemoto 1987). In oceanic regions where temperature does not fluctuate rapidly, K varies with food concentration (Kiørboe et al. 1982). Dagg \& Walser (1987) showed that gut passage time increased at progressively lower food concentrations. Shorter gut clearance time with increasing food concentration was shown in cladocerans (Murtaugh 1985), and in copepods (Baars and Oosterhuis 1984). We did not find significant correlation between $\mathrm{K}$ and $\mathrm{Chl} a$ concentration in this study. There are no gut fluorescence studies carried out on copepods from the Indian Ocean for comparison. Thus our study is useful in discerning the $\mathrm{K}$ values for estimating ingestion rates of copepods in the Indian Ocean.

The grazing impact of copepods is reported to account for as less as $1-12 \%$ of the primary production in the equatorial Pacific (Dam et al. 1995) and off NW Spain in the North Atlantic (Barquero et al. 1998) to moderate at 27-52 \% in the Arabian Sea (Roman et al. 2000; Table 3). It is reported to be 35-66\% in the Indian sector of the Southern Ocean (Mayzaud et al. 2002a). We found a large variability of 13-83\% in the Bay of Bengal. Bautista and Harris (1992) explain that up to $40 \%$ of copepod grazing on PP is possible if the $>10 \mu \mathrm{m}$ fraction of the phytoplankton increases. Within the oligotrophic Bay, the western transect has relatively higher nutrient concentrations and where larger phytoplankton cells such as Chaetoceros lorenzianus, $C$. curvisetus, C. didymus, Bacteriastrum furcatam and B. comosum were found irrespective of seasons (Paul et al. 2008). Incidently, the ingestion rate in the range of 2- $5.3 \mathrm{ng} \mathrm{chl}^{\text {eq. }}$ copepod $^{-}$ ${ }^{1} \mathrm{~h}^{-1}$ was also higher in this transect.

According to Calbet et al (2009), mesozooplankton grazing becomes important in regions of low primary productivity such as the Bay of Bengal. Similar to our observations, Huskin et al. (2001b) and Li et al. (2003) also found highly variable grazing rates, respectively 6-150\% off Azores and 25-141\% in the Bohai Sea. As zooplankton standing stocks/live biomasses are often higher than those of phytoplankton, such extreme range is likely. The zooplankton ingestion rates measured in this study are based on phytoplankton consumption alone. This means that non-fluorescent organic matter of autochthonous/ allochthonous origin, protozoans and fecal 
pellets are not accounted for in the gut fluorescence. However, they may constitute an important part of the copepod diet in the Bay of Bengal especially in the western region as has been variously noted earlier (Dam et al. 1995, Verity and Paffenhöffer 1996, Roman and Gauzens 1997, Del Giorgio and Duarte 2002).

\subsection{Respiration}

Apart from defecation, respiration is the other means of direct mineralization of ingested carbon. Environmental temperature, body size and locomotion play a vital role in regulating the respiration rates (Ikeda 1985; Mazzocchi and Paffenhöfer 1999). Copepod respiration rates ranging from 3.9 to $7.7 \mu 1 \mathrm{O}_{2}$ copepod $^{-1} \mathrm{~d}^{-1}$ obtained in this study are higher than those reported from temperate regions and compare quite closely with the ranges in the Pacific Ocean (Table 3). The higher rates in our study were in spite of the $12 \mathrm{~h}$ non-feeding during experimental duration, which according to Thor et al. (2003) can reduce the respiration by $50 \%$. Li et al. (2004) found that higher respiration rates in Calanus sinicus $\left(5-20 \mu \mathrm{O}_{2}\right.$ ind. $\left.^{-1} \mathrm{~d}^{-1}\right)$ were often associated with high temperature in the Yellow Sea. Gaudy and Boucher (1983) found higher rates ranging from 5.5 to $31 \mu \mathrm{O} \mathrm{O}_{2}$ ind. $^{-1} \mathrm{~h}^{-1}$ in the equatorial Indian Ocean. Greater specific respiration rates of zooplankton in the Bay of Bengal and in other tropical waters, as Hernandez-Leon and Ikeda (2005) highlight, are due to the combined effects of warmer temperatures and smaller body size of individuals.

Recently Bode et al (2013) found respiration rates of copepods in the northern Benguela system ranging from $1.44 \pm 0.72$ for small species to $38.4 \pm 12$ in larger ones like Eucalanus. From the morphological characteristics of feeding organs, Timonin (1971) reported that 50-80\% of zooplankton in the Indian Ocean were carnivores and Motoda and Minoda (1972) reported that only $20-27 \%$ of zooplankton numbers in the Kuroshio region were herbivores. If a lower RQ such as 0.7 for the protein metabolism in zooplankton, the respiration would have been still smaller. But since they are ammonotelic organisms (Omori and Ikeda 1984), a value of 0.97 has been used in this study. Zooplankton community respiration ranging from 26 to $90 \mathrm{mg} \mathrm{C} \mathrm{m}^{-2} \mathrm{~d}^{-1}$ in our study accounted for $\sim 50 \%$ of carbon ingested through grazing (Fig.7). These rates are greater than the estimate of 33\% suggested by Valiela (1984). Dam et al. (1995) found mesozooplankton respiration averaging $20 \%$ of the daily PP at the Bermuda Atlantic time-series station (BATS). In our study, respiration to PP ratios ranging from $22-68 \%$ were higher during 
SpIM. Teira et al. (2001) has found that phytoplankton release a higher percent of extracellular DOC in waters of low primary productivity release. This DOC is available for heterotrophic bacterial uptake. Therefore less productive ecosystems are more likely to have higher respiration to $\mathrm{PP}$ ratios.

\subsection{Growth and Production rates}

Zooplankton growth rates in the range of $0.33-0.45 \mathrm{~d}^{-1}$ are reported for smaller copepod species in the equatorial countercurrent of the Indian Ocean (Table 3; Sazhina 1985). The growth rates of $0.23-0.26 \mathrm{~d}^{-1}$ in the Bay are higher than those obtained in the Arabian Sea $\left(0.12 \mathrm{~d}^{-1}\right.$; Roman et al. 2000) or, at BATS ( $0.15 \mathrm{~d}^{-1}$ ) and Hawaiian ocean time-series (HOTS, $0.17 \mathrm{~d}^{-1}$; Roman et al. 2002 a). The higher growth rates which are mainly considered to be a function of temperature and body size in this study are higher because the Bay of Bengal is a warm pool almost throughout the year and the size of zooplankton which are mostly copepods, small. For eg. the $g$, was as high as $0.9 \mathrm{~d}^{-1}$ for the nauplii of Paracalanus spp. in the near shore waters off Jamaica, at $28^{\circ} \mathrm{C}$ (Hopcroft et al. 1998). High growth rates were found in studies (Hopcropt and Roff, 1998) where warm waters accompanied with ample food supply allowed the copepods to grow rapidly. As also observed by Huntley and Lopez (1992) and Turner (2004), the mesozooplankton in the Bay of Bengal, comprising mostly small copepod species such as Oncaea venusta, Paracalanus indicus, Oithona similis, Clausocalanus arcuicornis and Pleuromamma indica appear to have high fecundity and growth rates at warmer SST of $\geq 28^{\circ} \mathrm{C}$.

Zooplankton production rate derived in this study is similar in the central $(145 \pm 148 \mathrm{mg} \mathrm{C}$ $\left.\mathrm{m}^{-2} \mathrm{~d}^{-1}\right)$ and coastal $(130 \pm 164)$ waters of the Bay and are close to the estimates from the Arabian Sea (156 $\mathrm{mg} \mathrm{C} \mathrm{m}^{-2} \mathrm{~d}^{-1}$; Roman et al. 2000). The average zooplankton production: primary production ratios estimated for the Arabian Sea (0.12; Roman et al. 2000), BATS (0.03; Roman et al. 2002a) and HOTS (0.05; Roman et al. 2002b) are lower than our estimates of 0.26-1.87 owing mainly to lower primary production in the Bay (Prasanna Kumar et al 2010 a, b). 


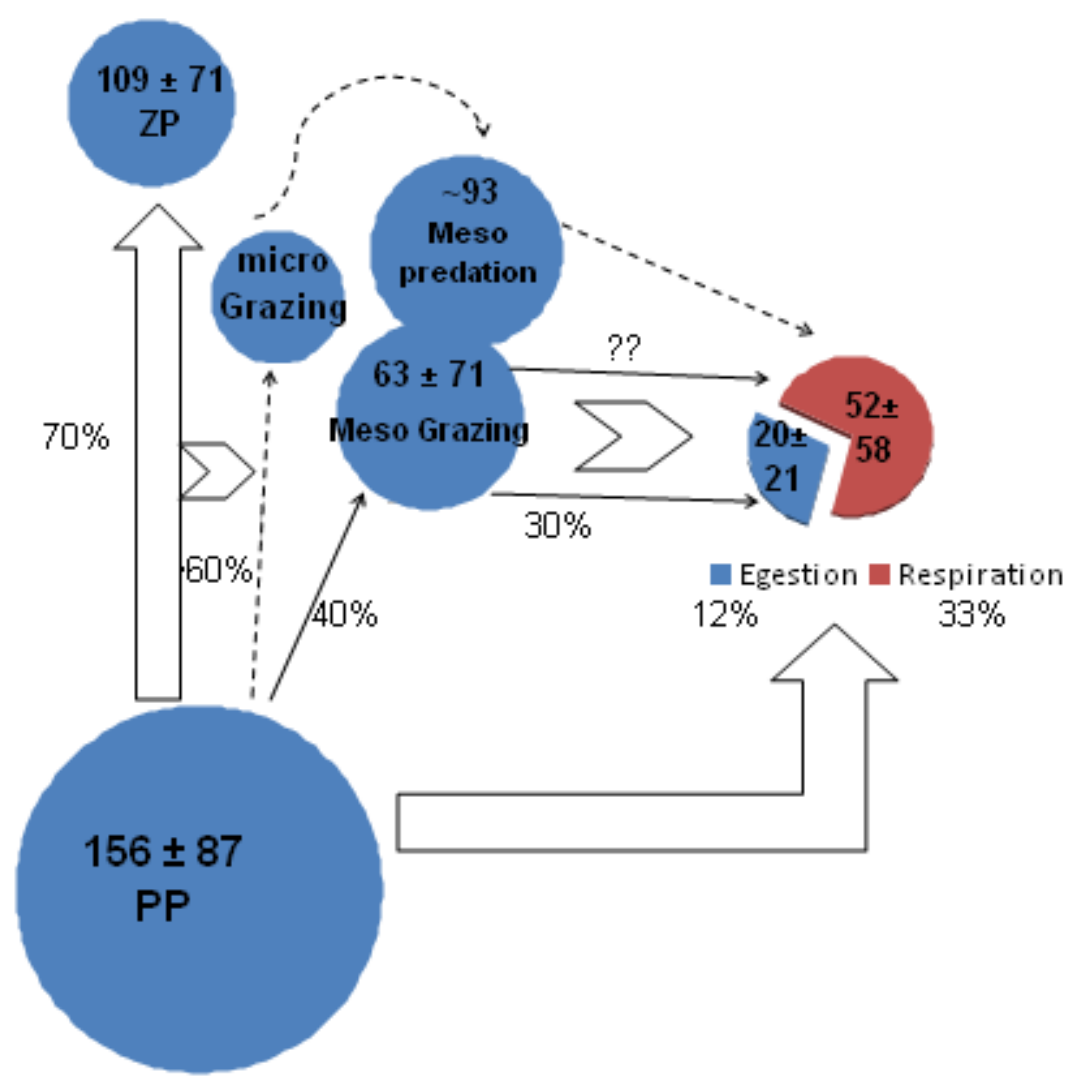

Fig.8. Basin-wide (2.2 million sq. km area ) carbon flow in the Bay of Bengal through zooplankton, depicting in $\mathrm{Mt} \mathrm{C}^{-1}$ of primary production (PP), zooplankton production (ZP) and their grazing, egestion and respiration rates estimated from measurements during this study. The larger fraction of PP is presumed to be routed through the dotted pathway with microzooplankton as the key component (not measured in this study). 


\subsection{Basin-wide estimates of carbon transfer}

Our first reports of mesozooplankton vital rates reveal that their contribution to the removal of carbon from photosynthesizers is enormous in the relatively less explored Bay of Bengal. Such contribution appears to be true for other regions as well (Hernandez-Leon and Ikeda 2005). It is evident from our previous studies (Prasanna Kumar et al. 2004, 2007, 2010a, b) that strong thermohaline stratification, perennial cloud cover, turbidity and weaker winds keep primary production low to moderate (156 Mt C y ${ }^{-1}$, Fig. 8) in the Bay of Bengal. Of the $63 \mathrm{Mt} \mathrm{C} \mathrm{y}^{-1}$ that is grazed by mesozooplankton, $30 \%$ is egested in the form of fecal pellets. But the respiration which accounts for $52 \mathrm{Mt} \mathrm{C} \mathrm{y}^{-1}$ cannot be met through grazing alone. Isla and Anadón (2004) found that the phytoplankton ingested by mesozooplankton was not able to support their basal metabolism and had to be complemented by protein diet. As only few copepods are pure herbivorous, most are omnivorous, and heterotrophic flagellates, ciliates and nauplii may be an important food source for them (Lampitt \& Gamble 1982, Tiselius 1989). Therefore, we propose that $\sim 60 \%$ of the PP is routed to mesozooplankton via the microzooplankton.

Further, as shown by Khodse et al. (2009), the particulate matter predominantly of terrigenous origin during SpIM and from diatoms during SUM and FIM form the major source of organic carbon to the heterotrophs. The dominant copepods found throughout the study are Oncaea venusta, which are very versatile in their food habits (Turner 1986, Paffenhöfer 1993). Not only Oncaea but as stated above, most copepods are in fact omnivores. This seems to favor the mesozooplankton that can make the best use of available phytoplankton and microzooplankton from within the system and also subsidize with the detritus brought in by rivers. The very high zooplankton production projected at $109 \mathrm{Mt} \mathrm{C} \mathrm{y}^{-1}$ together with basin-wide bacterial production ( $90 \mathrm{Mt} \mathrm{Cy}^{-1}$; derived from Ramaiah et al. 2010) gives a heterotrophic production (without accounting for microzooplankton) that exceeds the primary production.

Our annual estimate of zooplankton fecal pellet egestion amounts to $8.8 \mathrm{gC} \mathrm{m}^{-2}$ for the study area and $20 \mathrm{Mt} \mathrm{C}$ for the entire basin. This is 3 times the particulate organic carbon flux estimated through sediment trap data $\left(3.3 \mathrm{gC} \mathrm{m}^{-2} \mathrm{y}^{-1}\right.$; Honjo et al. 2008). From studies of Isla and Anadón (2004), it is evidenced that the contribution of vertically migrating mesozooplankton to the active fluxes of organic matter below the photic zone is less in the oceanic waters. The lower value in the sediment traps may be due to fecal pellet recycling in the water column through 
coprophagy and coprohexy (Fortier et al. 1994) or, even due to rapid regeneration by prokaryotic /heterotrophic processes in the euphotic zone (Cushing 1989, Fernandes et al. 2008).

The annual respiration of $52 \mathrm{Mt} \mathrm{C}$ by mesozooplankton from the mixed layer in the Bay

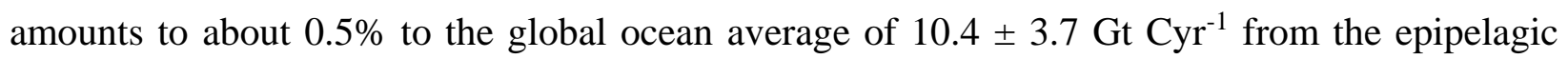
layer (Hernandez-Leon and Ikeda 2005). Considering that the area of the Bay is $\sim 0.6 \%$ of the global ocean, the carbon respiration we arrived at is apparently agreeable. It is also important to note that the mesozooplankton respiration in the Bay accounts for $33 \%$ of PP vis a vis the reported global range of $17-32 \%$.

\section{Conclusion}

Our study indicates that the low (primary) productive Bay of Bengal is characterized by relatively high heterotrophic (zooplankton) production averaging $70 \%$ of the primary production. There is a clear temporal shift in zooplankton control of primary production, especially during SpIM in the central Bay (ZP: PP, 188\% and Grazing: PP 83\%) in both oceanic and coastal transects. In low PP regions, proportionally more carbon is transferred to zooplankton (Strömberg et al. 2009). This hypothesis was also tested in the open Atlantic Ocean by Calbet et al (2009), who believe that since the primary productivity in oligotrophic systems is primarily due to picoplankton, a size that is not feasible for the mesozooplankton feeding, they probably become conditioned to effective feeding on larger microphytoplankton cells. A relatively high zooplankton production is apparently fuelled by the allochthonous carbon inputs from the numerous rivers, resulting in an inverse plankton pyramid. Warm pool regions such as these, where the surface waters are stable and often depleted in nitrate are likely to support high zooplankton production and biomass via microbially mediated regenerated production and cyclonic eddy-generated new production in the oceanic waters and by terrestrial inputs in the coastal waters.

From our results it is possible to suggest that in this warm pool region, net heterotrophy is likely to prevail in the mixed layer during SUM in the central Bay and in both transects during the warmer SpIM season. Sarma et al. (2004) reported net heterotrophic conditions in the eastern Arabian Sea where zooplankton grazing exceeds phytoplankton growth mostly during the

intermonsoons. Akin to findings of Regaudie-de-Giouxthe et al (2009), net heterotrophy could accelerate carbon export by zooplankton in the Bay in the form of carcass sinking/moulting/feces 
into the subsurface. The implications of this study is that if net heterotrophic conditions continue, the Bay of Bengal will become a source of carbon dioxide and sink of organic matter and oxygen- which might result in the expansion of the already large oxygen minimum zone.

\section{Acknowledgments}

We thank Directors Dr. S.R. Shetye and Dr. SWA Naqvi CSIR-NIO for facilities and encouragement. This work was supported by the grants from Ministry of Earth Sciences, Government of India under the BoBPS Programme. VF acknowledges the CSIR for the financial support during the Senior Research Fellowship and Research Associateship tenures. This is NIO contribution number...

\section{References}

Achuthankutty, C.T., Madhupratap, M., Nair, V.R., Nair, S.R.S., Rao, T.S.S., 1980. Zooplankton biomass and composition in the western Bay of Bengal during late Southwest monsoon. Indian J. Mar. Sci. 9, 201-206.

Anjusha, A., Jyothibabu, R., Jagadeesan, L., Mohan, A.P., Sudheesh, K., Krishna, K., Ullas, N., Deepak, M.P., 2013. Trophic efficiency of plankton food webs: Observations from the Gulf of Mannar and the Palk Bay, Southeast Coast of India. J. Mar. Syst. 115, 40-61.

Baars, M.A., Oosterhuis, S.S., 1984. Diurnal feeding rhythms in North Sea copepods measured by gut fluorescence, digestive enzyme activity and grazing on labelled food. Neth. J. Sea Res. 18, 97-119.

Banse, K., 1988. Estimates of average phytoplankton division rates in the open Arabian Sea. Indian J. Mar. Sci. 17, 31-36.

Barquero, S., Cabal, J.A,, Anadón, R., Fernández, E., Varela, M., Bode, A., 1998. Ingestion rates of phytoplankton by copepod size fractions on a bloom associated with an off-shelf front off NW Spain. J. Plankton Res. 20, 957-972.

Bautista, B., Harris, R.P., 1992. Copepod gut contents, ingestion rates and grazing impact on phytoplankton in relation to size structure of zooplankton and phytoplankton during a spring bloom. Mar. Ecol. Prog. Ser. 82, 41-50.

Besiktepe, S., 2001. Diel vertical distribution, and herbivory of copepods in the southwestern part of the Black Sea. J. Mar. Sys. 28, 281-301. 
Besiktepe, S., Svetlichny, L., Yuneva, T., Romanova, Z., Shulman, G., 2005. Diurnal gut pigment rhythm and metabolic rate of Calanus euxinus in the Black Sea. Mar. Biol. 146, 1189-1198.

Bode, M., Schukat, A., Hagen, W., Holger A., 2013. Predicting metabolic rates of calanoid copepods. Journal Exp. Mar. Biol. Ecol. 444, 1-7.

Calbet, A., Atienza, D., Henriksen, C.I., Saiz, E., Adey, T.R., 2009. Zooplankton grazing in the Atlantic Ocean: A latitudinal study. Deep-Sea Res. II 56, 954-963.

Conover, R., 1978. Transformations of organic matter. In: Kinne O. (ed) Marine Ecology 4. Dynamics. Wiley, Chichester, pp 221-499.

Cushing, D.H., 1989. A difference in structure between ecosystems in strongly stratified waters and in those that are only weakly stratified. J. Plankton Res. 11, 1-13.

Dagg, M.J., Wyman, K.D., 1983. Natural ingestion rates of the copepods Neocalanus plumchrus and N. cristatus calculated from gut contents. Mar. Ecol. Prog. Ser. 13, 37-46.

Dagg, M. J., Walser, W. E., 1987. Ingestion, gut passage, and egestion by the copepod Neocalanus plumchrus in the laboratory and in the subarctic Pacific Ocean. Limnol. Oceanogr. 32, 178-188.

Dam, H.G., Peterson, W.T., 1988. The effect of temperature on the gut clearance rate constant of planktonic copepods. J. Exp. Mar. Biol. Ecol. 13, 37-46.

Dam, H.G., Roman, M.R., Youngbluth, M.J., 1995. Downward export of respiratory carbon and dissolved inorganic nitrogen by diel-migrant mesozooplankton at the JGOFS Bermuda timeseries station. Deep-Sea Res. I 42, 1187-1197.

Decima, M., Landry, M.R., Rykaczewski, R.R., 2011. Broad scale patterns in mesozooplankton biomass and grazing in the eastern equatorial Pacific. Deep-Sea Res. II 58, 87-399.

Duarte C.M., Regaudie-de-Gioux, A., Arrieta J.M., Delgado-Huertas, A., Agusti, S., 2013. The oligotrophic ocean is heterotrophic. Annu. Rev. Marine. Sci. 5, 551-569.

Del Giorgio, P.A., Duarte, C.M., 2002. Respiration in the open ocean. Nature 420, 79-384.

Fernandes, V., 2008 The effect of semi-permanent eddies on the distribution of mesozooplankton in the central Bay of Bengal. J. Mar. Res. 4, 465-488.

Fernandes, V., Ramaiah, N., Paul, J.T., Sardessai, S., Jyothibabu, R., Gauns, M., 2008. Strong variability in bacterioplankton abundance and production in central and western Bay of Bengal. Mar. Biol. 153, 975-985. 
Fernandes, V., Ramaiah, N., 2009. Mesozooplankton community in the Bay of Bengal (India): spatial variability during the summer monsoon. Aquat. Ecol. 43, 951-963.

Fernandes, V., Ramaiah, N., 2013. Mesozooplankton community structure in the upper $1000 \mathrm{~m}$ along the western Bay of Bengal during the 2002 Fall Intermonsoon. Zool. Stud. 52, 31.

Fortier, L., Le Fevere, J., Legendre, L., 1994. Export of biogenic carbon to fish and to deep ocean: the role of large planktonic microphages. J. Plankton Res. 16, 809-839.

Gaudy, R., Boucher, J., 1983. Relation between respiration, excretion (ammonia and inorganic phosphorus) and activity of amylase and trypsin in different species of pelagic copepods from an Indian Ocean equatorial area. Mar. Biol. 75, 37-45.

Grice, G.D, Hart, A.D., 1962. The abundance, seasonal occurrence and distribution of the epizooplankton between New York and Bermuda. Ecol. Monogr. 34, 287-309.

Grasshoff, K., Ehrhardt, M., Kremling, K., 1983. Methods of seawater analysis. In: Ehrhardt M, Kremling K (eds) second revised, extended edition. Verlag Chemie, Weinheim, Germany, pp 419.

Harris, R.P., Wiebe, P.H., Lenz, J.H, Skjoldal, R., Huntley, M., (eds) 2000. ICES zooplankton methodology manual. Academic Press, San Diego.

Harrison, W.G., Arístegui, J., Head, E.J.H., Li, W.K.W., Longhurst, A.R., Sameoto, D.D., 2001 Basin-scale variability in plankton biomass and community metabolism in the sub-tropical North Atlantic Ocean. Deep-Sea Res. II 48, 2241-2269.

Head, E.J.H., Harris, L.R., 1996. Chlorophyll destruction by Calanus spp. grazing on phytoplankton kinetics, effects of ingestion rate and feeding history and a mechanistic interpretation Mar. Ecol. Prog. Ser. 135, 223-235.

Hernandez-Leon, S., Ikeda, T., 2005. A global assessment of mesozooplankton respiration in the ocean. J. Plankton Res. 27, 153-158.

Hirst, A. G. and Lampitt, R. S., 1998. Towards a global model of in situ weight-specific growth in marine planktonic copepods. Mar. Biol. 132, 247-257.

Hirst, A.G., Sheader, M., 1997. Are in situ weight-specific growth rates body-size independent in marine planktonic copepods? A re-analysis of the global syntheses and a new empirical model. Mar. Ecol. Prog. Ser. 154, 155-165.

Hopcroft, R.R., Roff, J.C., 1998. Zooplankton growth rates: the influence of female size and resources on egg production of tropical marine copepods. Mar. Biol. 132, 79-86. 
Hopcroft, R.R., Roff, J.C., Webber, M.K., Witt, J.D.S., 1998. Zooplankton growth rates: the influence of size and resources in tropical marine copepodites. Mar. Biol. 132, 67-77.

Huntley, M.E., Lopez, M.D.G., 1992. Temperature-dependent production of marine copepods: A global synthesis. Am. Nat. 140, 201-242.

Huskin, I, Anadon, R, Woodd-Walker, R.S., Harris, R.P., 2001a. Basin-scale latitudinal patterns of copepod grazing in the Atlantic Ocean. J. Plankton Res. 23, 1361-1371.

Huskin, I., Anadon, R., Medina, G., Head, R.N., Harris, R.P., 2001b. Mesozooplankton distribution and copepod grazing in the subtropical Atlantic near the Azores: Influence of mesoscale structures. J. Plankton Res. 23, 671-691.

Honjo, S., Manganini, S.J., Krishfield, R.A., Francois, R., 2008. Particulate organic carbon fluxes to the ocean interior and factors controlling the biological pump: a synthesis of global sediment trap programs since 1983. Prog. Oceanogr. 76, 217-85.

Ikeda, T., 1985. Metabolic rates of epipelagic marine zooplankton as a function of body mass and temperature. Mar. Biol. 85, 1-11.

Ikeda, T., Kanno, Y., Ozaki, K., Shinada, A., 2001. Metabolic rates of epipelagic marine copepods as a function of body mass and temperature. Mar. Biol. 139, 587-596.

Isla, J. A., Anadón , R., 2004. Mesozooplankton size-fractionated metabolism and feeding off NW Spain during autumn: effects of a poleward current ICES J. Mar. Sci. 61, 526-534.

Jyothibabu, R., Madhu, N.V., Maheswaran, P.A., Jayalakshmy, K.V., Nair, K.K.C., Achuthankutty, C.T., 2008. Seasonal variation of microzooplankton (20-200 $\mu \mathrm{m})$ and its possible implications on the vertical carbon flux in the western Bay of Bengal. Cont. Shelf Res. 28, 737-755.

Karl, D. M., Christian, J. R., Dore, J. E., Hebel, D.V., Letelier, R. M., Tupas, L. M., Winn, C. W., 1996. Seasonal and interannual variability in primary production and particulate flux at station ALOHA Deep Sea Res. II 43, 359-568.

Kasturirangan, L.R., 1963. A key for the identification of the more common planktonic copepoda of Indian coastal waters. In: Panikkar NK (ed) Indian National Committee on Oceanic Research, Publication 2. Council of Scientific and Industrial Research, New Delhi, pp 1-87.

Khodse, V.B., Bhosle, N.B., Gopalkrishna, V.V., 2009. Distribution of particulate carbohydrate species in the Bay of Bengal. J. Earth Syst. Sci. 118, 147-156. 
Kiørboe, T., 1997. Population regulation and role of mesozooplankton in shaping marine pelagic food webs, Hydrobiologia 363, 13-27,

Kiørboe, T., Mohlenberg, F., Nicolajsen, H., 1982. Ingestion rate and gut clearance in the planktonic copepod Centropages hamatus (Lilljeborg) in relation to food concentration and temperature. Ophelia 21, 181-194.

King, F.D., Devol, A.H., Packard, T.T., 1978. Plankton metabolic activity in the eastern tropical North Pacific. Deep-Sea Res. 25, 689-704.

Kumar, S., Ramesh, R. 2005. Productivity measurements in the Bay of Bengal using the ${ }^{15} \mathrm{~N}$ tracer: Implications to the global carbon cycle. Indian J. Mar. Sci. 34, 153-162.

Lampitt, R.S., Gamble, J.C. 1982. diet and respiration of the small planktonic marine copepod Oithona nana. Mar. Biol. 66,185-190.

Le Borgne, R., 1982. Zooplankton production in the eastern tropical Atlantic Ocean: net growth efficiency and P: B in terms of carbon, nitrogen and phosphorus. Limnol. Oceanogr. 27, 681698.

Li, C., Wang, R., Sun, S., 2003. Grazing impact of copepods on phytoplankton in the Bohai Sea. Est. Coast. Shelf Sci. 58, 487-498.

Li, C., Sun, S., Wang, R., Wan, X., 2004. Feeding and respiration rates of a planktonic copepod (Calanus sinicus) over summering in Yellow Sea cold bottom waters. Mar. Biol. 145, 149157.

Mackas, D., Bohrer, R., 1976. Fluorescence analysis of zooplankton gut contents and an investigation of diel feeding patterns. J. Exp. Mar. Biol. Ecol. 25, 77-85.

Madhupratap, M, Achuthankutty, C.T., Nair, S.R.S., Nair, V.R. 1981. Zooplankton abundance of the Andaman Sea. Indian J. Mar. Sci. 10, 258-261.

Madhupratap, M., Gopalakrishnan, T.C., Haridas, P., Nair, K.K.C., Aravindakshan, P.N., Padmavati, G., Paul, S., 1996. Lack of seasonal and geographic variation in mesozooplankton biomass in the Arabian Sea and its structure in the mixed layer. Curr. Sci. 71, 863-868.

Madhupratap, M., Gauns, M., Ramaiah, N., Prasanna Kumar, S., Muraleedharan, S.P.M., De Sousa, S.N., Sardessai, S., Muraleedharan, U., 2003. Biogeochemistry of the Bay of Bengal: physical, chemical and primary productivity characteristics of the central and western Bay of Bengal during summer monsoon 2001. Deep-Sea Res. II 50, 881-896. 
Marshall, S.M., 1973. Respiration and feeding in copepods. Adv. Mar. Biol. 11, 57-120.

Mazzocchi, M.G., Paffenhöfer, G.A., 1999. Swimming and feeding behavior of the planktonic copepod Clausocalanus furcatus. J. Plankton Res. 21, 1501-1518.

Mayzaud, P., Dallot, S. 1973. Respiration and nitrogen excretion of zooplankton. I. Evaluation of the metabolic rates of some western Mediterranean species. Mar. Biol. 19, 307-314.

Mayzaud, P., Tirelli, V., Errhif, A., Labat, J.P., Razouls, S., Perissinotto, R., 2002a. Carbon intake by zooplankton. Importance and role of zooplankton grazing in the Indian sector of the Southern Ocean. Deep-Sea Res. II 49, 3169-3187.

Mayzaud, P., Razouls, S., Errhifa, A., Tirellia, V., Labata, J.P., 2002b. Feeding, respiration and egg production rates of copepods during austral spring in the Indian sector of the Antarctic Ocean: role of the zooplankton community in carbon transformation. Deep-Sea Res. I 49, 1027-1048.

McKinnon, A. D. and Duggan, S.: Summer copepod production in subtropical waters adjacent to Australia's North West Cape, Mar. Biol., 143, 897-907, 2003.

Menzel, D.W., Ryther, J.H., 1960. Zooplankton in the Sargasso Sea off Bermuda and its relation to organic production. J. Cons. Perm. Int. Explor. Mer. 26, 250-258.

Morales, C.E., Harris, R.P., 1990. A review of the gut fluorescence method for estimating ingestion rates of planktonic herbivores ICES (International Council for the Exploration of the Sea), C M. 1990/L: 26, Biological Oceanographic Committee.

Morales, C.E., Bedo, A., Harris, R.P., Tranter, P.R.G., 1991. Grazing of copepod assemblages in the north-east Atlantic: the importance of the small size fraction. J. Plankton Res. 13, 455472.

Motoda, S., Minoda, T., 1972. Herbivorous zooplankton - food phytoplankton relationships in the western North Pacific (142EE). In: Sugawara, K. (ed.). Proceedings of the second symposium on the results of the cooperative study of the Kuroshio and adjacent regions: Saikon Publ. Co. Ltd, Tokyo. Volume: 213-217.

Mullin, M.M., 1966. Selective feeding by calanoid copepods from the Indian Ocean p 545-554. In Some contemporary studies in marine science. Barnes H (Ed) George Allan and Unwin Ltd., London.

Murtaugh, P.A., 1985. The influence of food concentration and feeding rate on the gut residence time of Daphnia. J. Plankton Res. 7, 413-420. 
Nair, S.S.R., Nair, V.R., Achuthankutty, C.T, Madhupratap, M. 1981. Zooplankton composition and diversity in western Bay of Bengal. J. Plankton Res. 3, 493-508.

Omori, M., Ikeda, T. 1984. Methods in marine zooplankton ecology. Wiley, New York, pp 332 Paffenhöfer, G.A., 1993. On the ecology of marine cyclopoid copepods (Crustacea, Copepoda). J. Plankton Res. 15, 37-55.

Paffenhöfer, G.A., Tzeng, M., Hristov, R., Smith, C.L., Mazzocchi, M.G., 2003. Abundance and distribution of nanoplankton in the epipelagic subtropical/tropical open Atlantic Ocean. J. Plankton Res. 25, 1535-1549.

Panikkar. N.K., Rao, T.S.S., 1973. Zooplankton investigation in Indian waters and the role of the Indian Ocean Biological Centre. In: Handbook to the international zooplankton collections, Vol. V, National Institute of Oceanography, Cochin (1973), pp 111-162.

Paul, J. T , Ramaiah, N., Sardessai S., 2008. Nutrient regimes and their effect on distribution of phytoplankton in the Bay of Bengal Mar. Environ. Res. 66, 337-344.

Penry, D. L., Frost, B. W., 1991. Chlorophyll a degradation by Calanus pacificus: dependence on ingestion rate and digestive acclimation to food resources. Limnol. Oceanogr. 36, 147-149.

Peterson, W. T., Painting, S. J., Barlow, R., 1990. Feeding rates of Calanoides carinatus: a comparison of five methods including evaluation of the gut fluorescence method Mar. Ecol. Prog. Ser. 63, 85-92.

Petipa, T., 1985. Digestion time and diurnal food rations in Copepoda of the dynamically active water masses in the Indian Ocean. Pol. Archiv. Hydrobiol. 32, 481-490.

Prasanna Kumar, S., Nuncio, M., Narvekar, J., Kumar, A., Sardessai, S., DeSouza, S.N., Gauns, M., Ramaiah, N., Madhupratap, M., 2004. Are eddies nature's trigger to enhance biological productivity in the Bay of Bengal? Geophys. Res. Letts. 31, L07309.

Prasanna Kumar, S., Nuncio, M., Ramaiah, N., Sardessai, S., Narvekar, J., Fernandes, V., Paul, J.T., 2007. Eddy-mediated biological productivity in the Bay of Bengal during fall and spring intermonsoons. Deep-Sea Res. I 54, 619-1640.

Prasanna Kumar, S., Narvekar, J., Nuncio, M., Kumar, A., Ramaiah, N., Sardessai, S., Gauns, M., Fernandes, V., Paul, J., 2010a. Is the biological productivity in the Bay of Bengal light limited? Curr. Sci. 98, 1331-1339. 
Prasanna Kumar, S., Nuncio, M., Narvekar, J., Ramaiah, N., Sardessai, S., Gauns, M., Fernandes, V., Paul, J.T., Jyothibabu R., Jayraj K.A., 2010b. Seasonal cycle of physical forcing and biological response in the Bay of Bengal. Indian J. Mar. Sci. 39, 388-405.

Rakhesh M, Raman, A.V. Sudarsan, D., 2006. Discriminating zooplankton assemblages in neritic and oceanic waters: A case for the Northeast coast of India, Bay of Bengal. Mar. Environ. Res. 61, 93-109.

Ramaiah, N., Fernandes, V., Rodrigues, V. V., Paul, J. T., Gauns M. 2009. Bacterioplankton abundance and production in Indian Ocean Regions. In: Indian Ocean Biogeochemical Processes and Ecological Variability. Geophys. Mon. Ser. 185, Am. Geophys. Union.185, $119-132$.

Ramaiah, N., Fernandes, V., Paul, J.T., Jyothibabu, R., Gauns, M., Jayraj, K.A. 2010. Seasonal variability in biological carbon biomass standing stocks and production in the surface layers of the Bay of Bengal. Indian J. Mar. Sci. 39, 369-379.

Regaudie-de-Gioux, A., Vaquer-Sunyer, R., Duarte, C.M. 2009. Patterns in planktonic metabolism in the Mediterranean Sea. Biogeosciences 6, 3081-89.

Roman, M.R., Dam, H.G., Gauzens, A.L., Napp, J.M. 1993. Zooplankton biomass and grazing at the JGOFS Sargasso Sea time series station. Deep-Sea Res. 40, 883-901.

Roman, M.R., Gauzens, A.L. 1997. Copepod grazing in the equatorial Pacific. Limnol. Oceanogr. 42, 623-634.

Roman, M., Smith, S., Wishne, K., Zhang, X, Gowing, M., 2000. Mesozooplankton production and grazing in the Arabian Sea. Deep-Sea Res. II 47, 1423-1450.

Roman, M.R., Adolf, H.A., Landry, M.R., Madin, L.P., Steinberg, D.K., Zhang, X. 2002a. Estimates of oceanic mesozooplankton production: a comparison using the Bermuda and Hawaii time-series data. Deep-Sea Res. II 49, 175-192.

Roman, M.R., Dam, H.G., Le Borgne, R., Zhang, X. 2002b. Latitudinal comparisons of equatorial Pacific zooplankton. Deep-Sea Res. II 49: 2695-2711.

Runge, J. A., Roff, J. C.: The measurement of growth and reproductive rates, in: ICES Zooplankton Methodology Manual, edited by: Harris, R., Wiebe, P., Lenz, J., Skjoldal, H. R., and Huntley, M., Academic Press, London, 2000

Sarma, V.V.S.S., 2004. Net plankton community production in the Arabian Sea based on $\mathrm{O}_{2}$ mass balance model. Glob. Biogeochem. Cy. GB4001, doi:10.1029/2003GB002198. 
Sautour, B, Artigas L.F, Delmas, D., Herbland, A., Laborde, P., 2000. Grazing impact of microand mesozooplankton during a spring situation in coastal waters off the Gironde Estuary. J. Plankton Res. 22: 531-552.

Sazhina, L. 1985. Fecundity and growth rate of copepods in diferent dynamic zones of Equatorial Countercurrent of the Indian Ocean. Pol. Archiv. Hydrobiol. 32, 491-505.

Schukat, A., Teuber, L., Hagen, W., Wasmund, N., Auel, H. 2013. Energetics and carbon budgets of dominant calanoid copepods in the northern Benguela upwelling system. J. Exp. Mar. Biol. Ecol. 442: 1-9.

Schneider, G., Lenz, J., 1987. Die Bedeutung der GroBenstruktur des Zooplanktons fur den Energietransfer impelagischen Okosystem der Auftriebsregion vor NW Afrika. Ber. Inst. Meereskde fie1 17.

Schneider, G., Lenz, J., 1991. Zooplankton community metabolism in the upper $200 \mathrm{~m}$ of the central Red Sea and the Gulf of Aden. Mar. Ecol. Prog. Ser. 77, 301-306.

Smith, S.L.,1982. The northwestern Indian Ocean during the monsoon of 1979: Distribution, abundance and feeding of zooplankton. Deep-Sea Res. 29, 1331-1353.

Strömberg, K.H.P., Smyth, T.J., Allen, J.I., Pitois, S., O’Brien, T.D. 2009. Estimation of global zooplankton biomass from satellite ocean colour. J. Mar. Sys. 78:18-27.

Teira, E., Pazo, M. J., Serret, P., Ferna'ndez , E., 2001. Dissolved organic carbon production by microbial populations in the Atlantic Ocean. Limnol. Oceanogr. 46, 1370-1377.

Thor, P., Dam, H.G., Rogers, D.R., 2003. Fate of organic carbon release from decomposing copepod fecal pellets in relation to bacterial production and ectoenzymatic activity. Mar. Ecol. Prog. Ser. 33, 279-288.

Timonin, A.G., 1971. The structure of plankton communities of the Indian Ocean. Mar. Biol. 9, 281-289.

Tiselius, P. T., 1989. Contribution of alloricate ciliates to the diet of Acartia clausi and Centropages hamatus in coastal species composition and vertical migration on the grazing water. Mar. Ecol. Prog. Ser. 56, 49-56.

Tseng, L.C., Kumar, R., Dahms, H.U., Chen, Q.C., Hwang, J.S. 2008. Copepod gut contents, ingestion rates, and feeding impacts in relation to their size structure in the southeastern Taiwan Strait. Zool. Stud. 47: 402-416. 
Tsuda, A., Nemoto, T. 1987. The effect of food concentration on the gut clearance time of Pseudocalanus minutus Kroyer (Calanoida: Copepoda). J. Exp. Mar. Biol. Ecol. 107:121130.

Turner, J.T., 1986. Zooplankton feedmg ecology: contents of fecal pellets of the cyclopoid copepods Oncaea venusta, Corycaeus amazonicus, Oithona plumifera, and O. simplex from the northern Gulf of Mexico. Mar. Ecol. 7, 289-302.

Turner, J.T., 2004. The importance of small planktonic copepods and their roles in pelagic marine food webs. Zool. Stud. 43, 255-266.

UNESCO, 1968. Zooplankton sampling. Monographs on oceanographic methodology. United Nations Educational, Scientific, and Cultural Organization (UNESCO), Paris, Publication no. 2

UNESCO, 1994. Protocols for the joint global ocean flux study (JGOFS). Manual and guides 29. United Nations Educational, Scientific, and Cultural Organization (UNESCO), Paris.

Venrick, G.L., 1990. Phytoplankton in an oligotrophic ocean: species structure and interannual variability. Ecology 71, 1547-1563.

Vinayachandran, P.N., Shetye, S.R. 1991. The warm pool in the Indian Ocean. Proc. Ind. Acad. Sci. (Earth Planet Sci) 100, 165-175.

Zhang, X., Dam, H.G., White, J.R., Roman, M.R., 1995. Latitudinal variations in mesozooplankton grazing and metabolism in the central tropical Pacific during the US JGOFS EqPac study. Deep-Sea Res. II 42: 695-714.

Verity, P.G., Paffenhöfer, G.A., 1996. On assessment of prey ingestion by copepods. J. Plankton Res. 18, 1767-1779.

Valiela, I., 1984. Marine ecological processes. Springer-Verlag. New York, p 546.

Wlodarczyk, E., Durbin, A.G., Durbin, E.G., 1992. Effect of temperature on lower feeding thresholds, gut evacuation rate, and diel feeding behavior in the copepod Acartia hudsonica. Mar. Ecol. Prog. Ser. 85, 93-106.

Yamaguchi, A., Matsuno, K., Abe, Y., Arima, D., Imai I., 2015.Latitudinal variations in the abundance, biomass, taxonomic composition and estimated production of epipelagic mesozooplankton along the $155^{\circ} \mathrm{E}$ longitude in the western North Pacific during spring. Prog. Oceanogr. (In Press, Corrected Proof) 
Table 2. Comparison of initial gut content $\left(\mathrm{G}_{0}\right)$, gut evacuation rate constant $(\mathrm{K})$ and ingestion rate (I) of copepods from various regions of the world ocean

\begin{tabular}{|c|c|c|c|c|}
\hline Area & $\begin{array}{l}\mathrm{G}_{0} \\
\left(\mathrm{ng} \operatorname{chl} a \mathrm{ind}^{-1}\right)\end{array}$ & $\begin{array}{l}\mathrm{K} \\
\left(\mathrm{h}^{-1}\right)\end{array}$ & $\begin{array}{c}\text { I } \\
\left.\text { (ng chl } a \text { eq. ind. } .^{-1} \mathrm{~d}^{-1}\right)\end{array}$ & References \\
\hline \multicolumn{5}{|l|}{ Temperate } \\
\hline 50N 48W; Off Plymouth, coastal & $0.1-0.9$ & $0.05-0.36$ & $10-200$ & Bautista and Harris 1992 \\
\hline 47-60N, 20W; N. Atlantic & $0.03-11.0$ & $0.72-2.04$ & $0.9-86$ & Morales et al. 1991 \\
\hline 45N, 2W; Gironde estuary & $0.2-0.5$ & 2.4-12 & $20-88$ & Sautour et al. 2000 \\
\hline 48-60S, 60-70E; Southern Ocean & $6.0-16.0$ & $0.66-1.13$ & $9-65$ & Mayzaud et al. 2002 b \\
\hline 42-43N, 29-34E; SW Black Sea & $0.1-9.1$ & 2.4 & $3.1-22$ & Besiktepe 2001 \\
\hline \multicolumn{5}{|l|}{ Subtropic } \\
\hline 43-44N, 8-9W; NW Spain, N. Atlantic coast & $0.1-0.6$ & $0.72-1.4$ & $20-80$ & Barquero et al. 1998 \\
\hline 41N, 72W; Long Island Sound estuary, Atlantic & $0.3-4.2$ & $0.3-3.5$ & - & Dam and Peterson 1998 \\
\hline 41N, 71W; Narrangansett Bay, Atlantic Ocean & $0.7-1.7$ & $1.87-2.8$ & $19-145$ & Wlodarczyk et al. 1992 \\
\hline 39N, 141E; Otsuchi Bay & $0.1-2.7$ & $0.3-0.63$ & - & Tsuda and Nemoto 1987 \\
\hline 37-40N, 118W; Bohai Sea & $1.1-2.7$ & $0.96-1.02$ & $14-37$ & Li et al. 2003 \\
\hline 27-39N, 19-33W; Azores & $0.15-4.64$ & $1.74-1.92$ & $\mathrm{H}$ & Huskin et al. 2001b \\
\hline 22-24N, 119-120W; SE Taiwan Strait & $0.2-2.0$ & - & $6-36$ & Tseng et al. 2008 \\
\hline \multicolumn{5}{|l|}{ Tropic } \\
\hline 9-20N, 81-88E; Bay of Bengal & $2.4-8.1$ & $0.4-0.94$ & $48-126$ & This study* \\
\hline
\end{tabular}

'-' denotes no data. $*$ This is the only study where these three copepod measurements have been made in the tropical ocean 
Table 3 Comparison of rates of copepod grazing $(\mathrm{G})$, Respiration $(\mathrm{R})$ and growth rate $(g)$ and ratios of Grazing to primary production (G:PP), zooplankton production to primary production (ZP:PP) and Fecal pellet to Total carbon flux from sediment trap (Fp:TcFlux) from different areas of world ocean.; AMT: Atlantic Meridional transent 50N-50S; BATS: Bermuda Atlantic Time Series Study; HOT: Hawaii Ocean Time Series; '-‘, no data

\begin{tabular}{|c|c|c|c|c|c|c|c|}
\hline$(\mathrm{mg}$ & $\begin{array}{l}\mathrm{G} \\
\left(\mathrm{m}^{-2} \mathrm{~d}^{-1}\right)\end{array}$ & $\underset{\left(\mu l \text { ind }^{-1} d^{-1}\right)}{R}$ & $\begin{array}{l}g \\
\mathrm{~d}^{-1}\end{array}$ & G: PP & ZP: PP & Fp: TcFlux & Reference \\
\hline Long Island Sound; estuary & - & $0.5-1.7$ & - & - & - & - & Thor et al. 2003 \\
\hline Antarctic Ocean & $81-84$ & $0.6-61$ & - & $0.35-0.66$ & - & - & Mayzaud et al. 2002a, 2002b \\
\hline Galician coast, NW Spain & $25-350$ & $0.1-1.6$ & - & $0.02-0.12$ & - & - & Ikeda et al. 2001, Barquero et al. 1998 \\
\hline Gironde estuary & $54-281$ & - & - & $0.09-0.40$ & - & - & Sautour et al. 2000 \\
\hline Black Sea & $9-246$ & - & - & $0.07-0.17$ & - & - & Besiktepe 2001 \\
\hline Azores, Atlantic Ocean & $2-85$ & - & - & $0.06-1.50$ & - & - & Huskin et al. 2001b \\
\hline AMT & $1.6-252$ & - & - & $0.08-0.13$ & - & - & Huskin et al. 2001a \\
\hline BATS & $37 \pm 12$ & - & 0.15 & $0.09 \pm 0.13$ & 0.03 & 0.42 & Roman et al. 2002a \\
\hline HOT & $90 \pm 29$ & - & 0.17 & $0.18 \pm 0.25$ & 0.05 & 1.05 & Roman et al. $2002 \mathrm{a}$ \\
\hline North Atlantic & $20-600$ & $0.6-5.6$ & - & $0.04-0.28$ & - & - & Calbet et al. 2009, Schneider and Lenz 1987 \\
\hline North Pacific & - & $2.0-5.2$ & - & - & - & - & King et al. 1978 \\
\hline Bohai Sea & $29-470$ & - & - & $0.25-1.41$ & - & - & Li et al. 2003 \\
\hline Yellow Sea & - & $5-20$ & - & - & - & - & Li et al. 2004 \\
\hline Equatorial Pacific & $24-180$ & $1.3-9.9$ & 0.17 & $0.01-0.32$ & 0.05 & 1.03 & $\begin{array}{l}\text { Roman \& Gauzens 1997, Shushkina \& Pavlova } \\
1973\end{array}$ \\
\hline Equatorial Pacific & $44-47$ & - & - & $0.01-0.12$ & 0.23 & 3.7 & Dam et al. 1995 \\
\hline Equatorial Pacific & $60-240$ & - & 0.19 & $0.28-0.42$ & 0.12 & 1.5 & Roman et al. 2002b \\
\hline Discovery Bay & - & - & 0.65 & - & - & - & Hopcroft and Roff 1998 \\
\hline Sargasso Sea & $3-51$ & $2.1-11$ & - & $0.09-0.26$ & - & - & Roman et al. 1993, Menzel and Ryther 1960 \\
\hline Arabian Sea & $120-1824$ & - & 0.12 & $0.27-0.52$ & 0.12 & $>1.0$ & Roman et al. 2000 \\
\hline Gulf of Aden & - & $2.0-3.4$ & - & - & - & - & Schneider and Lenz 1991 \\
\hline Equatorial Indian Ocean & - & $5.5-31$ & 0.39 & - & - & - & Sazhina 1985, Gaudy and Boucher 1983 \\
\hline Bay of Bengal & $26-134$ & $3.9-7.7$ & 0.25 & $0.13-0.83$ & 0.70 & 2.6 & This study \\
\hline
\end{tabular}

